\title{
The Relation between Religious Education Teachers' Perceptions of Organizational Justice and Job Satisfaction
}

Article History

Submitted: 31.07 .2018

Accepted: 20.03.2019

Published Online: 01.04.2019

Keywords

Organizational Justice Job Satisfaction

Religious Education

Teacher

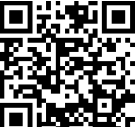

DOI: $10.29129 /$ inujgse.449760

\author{
Ali BALTACI \\ Muş Alparslan University, Muş - TURKEY
}

\section{Abstract}

Purpose: This research conducted to determine Religious Education (RE) teachers' perceptions of job satisfaction and organizational justice. In addition, the effect of organizational justice on job satisfaction will be determined within the scope of the study.

Design \& Methodology: This study was designed in a correlational screening model, from quantitative research methods to determine the relationship between RE teachers' perceptions of organizational justice and job satisfaction. The target universe of the research is $3396 \mathrm{RE}$ teachers worked in 39 provinces of Istanbul Province. The sample size determined by the proportional cluster sampling method considering the $95 \%$ confidence level and the confidence interval of $5 \%$ is 389 . Minnesota Job Satisfaction Scale developed by Baycan (1985) and Polat (2007) developed by Niehoff and Moorman (1996), developed by Weiss, Dawis, England \& Lofquist (1967) was used in this study. The data obtained with the measurement tools were analyzed by the SPSS program.

Findings: In the study, it was determined that RE teachers had 'mostly' perceptions of distributive, procedural and interactional justice. Likewise, the participants have 'mostly' in the sense of general organizational justice. Likewise, the participants have 'mostly' in the sense of general organizational justice. Participants were found to have 'moderate' individual and 'low' organizational job satisfaction. In addition, the overall level of job satisfaction of participants is also 'low'. However, distributional, procedural, and interactive justice differs significantly by gender, educational status, and professional tenure.

Implications \& Suggestions: It is necessary that those who guide the policies of education should dominate schools with a more transparent and accountable management approach that does not discriminate among teachers in accordance with ethical management principles. At this point, manager and teacher evaluation criteria can be audited and a suspended course and institutional audits can be made operational again. 


\section{Din Kültürü ve Ahlak Bilgisi Öğretmenlerinin Örgütsel Adalet Algısı ve İş Doyum Düzeyleri Arasındaki İlişki}

Makale Geçmişi

Geliş: 31.07.2018

Kabul: 20.03.2019

Online Yayın: 01.04.2019

Anahtar Sözcükler

Örgütsel Adalet

İş Doyumu

Din Eğitimi

Öğretmen
Ali BALTACI

Muş Alparslan Üniversitesi, Muş - TURKEY
Öz

Amaç: Bu araştırma, Din Kültürü ve Ahlak Bilgisi (DKAB) öğretmenlerinin, iş doyumları ile örgütsel adalet algılarının belirlenmesi amacıyla yürütülmüştür. Ayrıca örgütsel adaletin, iş doyumu üzerindeki etkisi de çalışma kapsamında belirlenecektir.

Yöntem: Bu çalışma, DKAB öğretmenlerinin örgütsel adalet algıları ile iş doyumları arasındaki ilişkiyi belirlemeye yönelik nicel araştırma yöntemlerinden, ilişkisel tarama modelinde tasarlanmıştır. Araştırmanın hedef evrenini, İstanbul İlinin 39 ilçesinde görev yapan 3396 DKAB öğretmeni oluşturmaktadır. Evrenden \%95'lik güven düzeyi ile \%5'lik güven aralı̆̆ dikkate alınarak oranlı küme örnekleme yöntemiyle belirlenen örneklem büyüklüğü 389'dur. Çalışmada Weiss, Dawis, England \& Lofquist (1967) tarafından geliştirilmiş olan ve Baycan (1985) tarafından Türkçeye uyarlanan Minnesota İş Doyum Ölçeği ile Niehoff ve Moorman (1996) tarafından geliştirilen Polat (2007) tarafından Türkçe'ye uyarlanan “Örgütsel Adalet Ölçeği” kullanılmıştır. Ölçme araçlarıyla elde edilen veriler, SPSS programıyla analiz edilmiştir.

Bulgular: Araştırmada DKAB öğretmenlerinin dağıtımsal, işlemsel ve etkileşimsel adalet algısına 'çoğunlukla' sahip oldukları belirlenmiştir. Benzer şekilde katılımcılar, genel örgütsel adalet algısına da 'çoğunlukla' sahiptirler. Katılımcıların 'orta' düzeyde bireysel ve 'az' düzeyde örgütsel iş doyumuna sahip oldukları saptanmıştır. Ayrıca katılımcıların genel iş doyumu seviyesi de 'az' düzeydedir. Bununla birlikte dağıtımsal, işlemsel ve etkileşimsel adalet cinsiyet, eğitim durumu ve mesleki kıdeme göre anlamlı bir şekilde farklılaşmaktadır.

Sonuçlar ve Öneriler: Eğitim politikalarına yön verenlerin, okullarda etik yönetim ilkelerine uygun, öğretmenler arasında ayrımcılığın yapıımadığı daha saydam ve hesapverebilir bir yönetim anlayışını okullarda egemen kılması gereklidir. Bu noktada, yönetici ve öğretmen değerlendirme ölçütleri gözden geçirilebilir ve bir süredir askıya alınan ders ve kurum denetimleri yeniden işler hale getirilebilir. 


\section{Giriş}

Gelişen teknik ve sosyal süreçler, örgütlere de yansımış; örgütün yönetim biçiminde radikal değişimlerin görülmesine yol açmıştır. Bu değişimlerden belki de en önemlisi örgütlerin daha şeffaf ve hesapverebilir olarak yapılanmaya başlamasıdır. Hesapverebilirlik, özü itibariyle örgütün tüm iş ve işlemlerinde belirli düzeyde sorumluluğu ve adil yönetim biçimini de beraberinde getirmiştir. Örgütlerde şeffaf karar mekanizmaların oluşturulması ile açık ve saydam bir yönetim anlayışı geliştirilebilir ve örgüt, paydaşlarınca daha kolay denetlenebilir bir yapıya kavuşur. Bu noktada adalet kavramı yönetim süreçlerine eklemlenmiş, örgütlerde uygulanan adalet ise kaynakların edinimi ve kullanımında yaşanan adilane uygulamalarda kendini göstermiştir. Örgütsel adalet, örgüt yönetiminin hak ve hukuk çerçevesinde yönetilmesi, alınan kararların hukuk kuralları ile çelişmemesi ve hukukun her durumda gözetilmesidir (DiPaola \& Tschannen-Moran, 2014; Greenberg \& Colquitt, 2013). Bu hali ile özel bir öneme sahip olan örgütsel adaletin, örgütlerde sağlanması, çalışanların işlerine karşı olumlu tutumlar geliştirmelerine olanak tanımıştır. İşe karşı olumlu tutumlar ise iş doyumu olarak adlandırılan bir sürece vurgu yapar. Dolayısıyla örgütsel adalet, esasında çalışanları iş doyumuna götüren uygulamalar bütünüdür (Klassen \& Chiu, 2010; Cohen, 1987).

Din, kişinin manevi ve dünyevi yaşamı ile kamusal alanı düzenleyen ilke, değer ve kurallar bütünü olarak tanımlandığında, doğası gereği adalet kavramını da içinde barındırır (Witte, 2006). Toplumun düzeni ve refahı için elzem olan adalet temelde önemli bir toplumsal değerdir (Saruhan, 2015) ve bir yönü ile de demokratik kültürün taşıyıcısıdır (Erdoğan, 2003). Toplumun değer ve kültürünün yeni nesillere aktarımı ise okul kültür ve ikliminin önemli bir parçasıdır ve tüm eğitim çalışanlarının ortak ilgisini zorunlu kılar. Bu bağlamda eğitim sistemi içerisinde öğrencilere kültürel değerler veya değerler eğitimi gibi konuların kazandırılması tüm öğretmenlerin ve okul yöneticilerinin sorumluluğudur (Deal \& Peterson, 2016). Bunun yanında eğitim sistemi içinde söz konusu kazanımlara ek olarak dini bilgileri öğrencilere kazandırmakla görevli olan din kültürü ve ahlak bilgisi (DKAB) öğretmenleri de bulunmaktadır. DKAB öğretmenleri, okullarda belirli bir dinin temsilcisi gibi görülürken, aynı zamanda o dinin kural ve kaidelerini de öğretme çabasındadırlar (Altaş, 2004). Bunun yanında, okullarda gerek okul çalışanları gerekse velilerce geleneksel olarak toplumun değer ve kültürünün de öğrencilere aktarılması DKAB öğretmenlerinin doğal sorumluluğu olarak görülmektedir (Baltacı \& Coşkun, 2018). Okullarda sıklıkla karşılaşılan bu hatalı algılayış ve düşünüş tarzı, bu çalışmanın yürütülmesindeki temel motivasyonu oluşturmaktadır.

Kamusal alanda ve kamu yapılanmasında esas alınan adaletin kökenlerinde din ve kültür olsa da genellikle salt dini kurallara göre işleyen bir toplumsal adalet sistemi kurgulanmamıştır. Yine de toplumsal yapıda din oldukça belirleyicidir ve pek çok yasal düzenlemenin de kökeninde dini esas ve içtihatlar yer almaktadır (Çarkoğlu \& Toprak, 2006). Bu yönü ile adalet kavramı din kavramından soyutlanamaz. 2017 yılı öncesi öğretim programlarında adalet kavramının okullarda bir değer olarak öğretimi çoğunlukla sosyal bilgiler dersine ait kazanımlarda yer almaktayken; okul sistemi içinde hak, hukuk ve adalet gibi değerlerin, yeni nesillere aktarılması görevi yenilenen DKAB programıyla birlikte büyük ölçüde DKAB öğretmenlerinin sorumluluğuna bırakılmıştı. Ancak 2017 yılında güncellenen öğretim müfredatları ile öğrencilere aktarılması hedeflenen kök değerler belirlenmiştir. Söz konusu kök değerler tüm ders müfredatlarında gerek kuramsal gerekse uygulamaya dönük etkinlikleri de içerecek şekilde yer almakta ve adalet, dostluk, dürüstlük, öz denetim, sabır, saygı, sevgi, sorumluluk, vatanseverlik, yardımseverlik gibi temel değerleri içermektedir. Bunun yanında adalet gibi disiplinler arası bir kavramın öğrencilere kazandırılması görevinde öncü konuma gelmiş olan DKAB öğretmenlerinin örgütsel adalet algılarının, onların okulu algılayış biçiminden ayrık olması da düşünülemez. DKAB öğretmenlerinin örgüt içindeki uygulama ve politikalara yönelik tutumları onların örgütsel adalet algılarını etkileyecek ve bu durumda 
onların işlerine yönelik olumlu veya olumsuz tutum ve davranışlar sergilemelerine neden olabilecektir. DKAB öğretmenlerinin örgütsel adalet algılarının, onların okula olan tutumlarını değiştirebileceği düşüncesi ile birlikte iş doyumlarının da etkileneceği öngörüsü bu çalışmanın ikincil motivasyon kaynağıdır.

Din eğitimi alanında çalışan öğretmenlerin de adalet kavramına ilişkin duygu ve düşüncelerinin belirlenmesi, okullarda var olan kültür aktarımı ve değerler eğitimi çalışmalarının verimliliğinin izlenmesi açısından önemlidir. Toplumun kültürüne yön veren bir değer olarak adalet kavramını içselleştirmemiş bir öğretmenin, öğrencilere bu değeri aşılaması güç ve sorunlu olacaktır. Bunun yanında örgüt içinde yaşanan aksaklıkların farkına varıp bunlar hakkında önlem alınması noktasında ilgilileri uyarmak salt DKAB öğretmenlerinin değil, tüm eğitim çalışanlarının sorumluluğudur (Brighouse, 2003). Bu noktada okullarda DKAB öğretmenlerinden beklenen genel tutum, çeşitli sorunların dini, ahlaki ve vicdani yönüne odaklanıp farklı ve özgün çözüm önerilerini sunabilmeleridir. Aldıkları dini ve ahlaki eğitimin bir gereği olarak okullarda DKAB öğretmenlerinden belirli ölçüde ahlaki ve vicdani davranmaları ve hak, hukuk ve adalet gibi kavramların uygulanmasında öncü olmaları yönündedir (Bayrakdar, 2014). Bu pratik beklenti sebebi ile DKAB öğretmenleri örgüte karşı olumsuz tutum geliştirebilmekte ve iş verimi ile iş doyumları düşebilmektedir. Bunun yanında bu çalışmanın örneklem grubunu oluşturan DKAB öğretmenleri, gerek okul içinde iş arkadaşlarınca gerekse veli ve öğretmenler tarafından belirli bir dinin kural ve sorumluluklarını kendilerine göre daha iyi bildikleri düşüncesi ile danışma makamı gibi algılanabilmektedirler (Baltacı \& Coşkun, 2018). Bu çalışmaya konu olan örneklem grubunun seçilme nedeni ise onların örgütsel adalet kavramına yönelik yaklaşımları ile salt verili değer ve kuralları içselleştirmesinden ziyade, dini kural ve sorumlulukların eşliğinde bir adalet algısına sahip olmalarındandır. Bu yönü ile bu çalışma DKAB öğretmenlerine atfedilen yoğun sorumluluğun meşruiyetinin sorgulanmasına da neden olabilir. Bunun yanında DKAB öğretmenlerinin örgütsel adalet algılarının ve iş doyumlarının belirlenmesi, okulda yaşanan farklı yönetimsel, etik ve eğitsel sorunların belirginleşmesini de sağlayacak, ayrıca öğretmenlerin adalet algısının onların iş doyumları üzerindeki etkisi de belirlenmeye çalışılacaktır. Örgütsel adalet algısı ile iş doyumu arasındaki etkileşime odaklanan bu çalışma, din eğitimi literatüründe henüz değinilmemiş bir konuyu ele alması bakımından önemlidir ve elde edilen verilerin yeni çalışma alanları açması muhtemeldir. İlerleyen bölümlerde örgütsel adalet ve iş doyumu kavramları tartışılacaktır.

\section{Örgütsel Adalet Kavramı}

Adalet, insanoğlunun tarihsel olarak ulaşmak istediği oldukça kapsamlı bir idealdir. Özünde sosyal bir olgu olarak beliren adalet kavramı, bireysel süreçleri de içeren çok yönlü bir yapıdadır. Kamusal alanda şekillenen adalet ilkeleri, ödül ve cezanın pratiklerini belirlemek, öznelerin haklarını ve kamusal alandaki bireysel sorumluluklarını çözümlemeye yardım eder (Greenberg, 1990). Adalet kavramının; bireylerin diğerlerine karşı eşit davranması veya belirli bir taraf tutmaması, hak ve hukuk kurallarına riayet etme gibi farklı tanımları yapılsa da kamusal alanda yaygın olarak haklılık ve doğruluğun ifadesi olarak kullanılmaktadır. Kavramın etimolojik kökenleri, dengeleme ve hak arama anlamlarına gelen Arapça "adl" sözcüğüyle ilişkilendirilmektedir (İçerli, 2010). Batı dünyasında kavramın kökenleri, ödül ya da ceza verilmesiyle haklı temsilde yargılanma yetkisinin kullanılması, adil ve adil olma niteliği, ahlaki tutarlılık ve gerçeğe uygunluk anlamlarına gelen Latince "justus/justitia" sözcüğünden gelmektedir. Tarihsel olarak Platon'dan John Locke'a ve Deluze'ye kadar farklı düşünürlerce tanımlar yapılmış olsa da güncel kullanımda adalet: bireylerin yaptığı bir davranışın veya tutumun, toplumca kabul görmüş otoritelerce belirlenen kurallara uygun olması, toplum içinde yaşayan bireylerin birbirleriyle ve devler ile karşılıklı ilişkilerinde doğruluk ve dürüstlüğünü ifade etmek için kullanılmaktadır (Skarlicki \& Latham, 1996). Çalışma ortamında adalet olgusu, çalışanların karşılıklı etkileşimlerinin yanında örgütün tüzel kimliğinin 
bir yansımasıdır. Bu açıdan örgütsel bir form kazanan adalet kavramı, örgüt içinde çalışanlara karşı yöneticilerin eşit ve adil davranması (Aryee, Budhwar, \& Chen, 2002; Colquitt, Conlon, Wesson, Porter, \& Ng, 2001; McFarlin \& Sweeney, 1992) ve çalışanları birbirleriyle ve örgütle olan etkileşimlerinde doğru ve dürüst bir etkileşim içinde olmalarını ifade eder (Cropanzano, Byrne, Bobocel, \& Rupp, 2001).

Adalet çoğunlukla eşitlik, tarafsızlık, hak ve hukuk kurallarına riayet etme gibi farklı kavramlar üzerinden tanımlanan ve toplum tarafından kabul görmüş ilkeleri içeren bir olgudur (Cohen, 1987). Bununla birlikte örgütsel adalet ise örgüt içinde çalışanlara veya hizmet alanlara hak ve hukuk kuralları çerçevesinde eşit davranılması gerektiğini konu edinir. Örgütsel adalet, çalışanlarla diğer çalışanların veya işveren ya da yöneticinin örgüt içi iletişiminin doğasını belirlemekte ve birleştirici bir perspektif sunmaktadır. Buna karşın adaletsizlik, örgüt içindeki iletişim kanallarını tıkayan, kişilerarası bağları çözen bir ayrıştırıcıdır (Greenberg, 1990). Örgütün başarısı, bireysel performanslardan ziyade, bütüncül bir anlayış ile birbirlerine bağlanmış çalışanların toplam performansına göre değerlendirilir. Bu noktada bir örgütte, çalışanların adalet algılarının gelişmişlik düzeyi, örgütün etkinliği ve başarısını da etkileyecektir (Colquitt vd., 2001).

Örgütsel kaynakların (ödül, ceza vb.) nasıl dağıtıldığı? Kaynak dağıtımını belirleyen ölçütlerin nasıl belirlendiği? Kaynak dağıtımına ilişkin kararların nasıl alındığı? gibi yönetimsel iş ve işlemlerin yürütülmesi sürecinde örgüt içi iletişimin nasıl olması gerektiğine yönelik kurallar ve sosyal normların birleşimi olan örgütsel adalet kavramı, tarihsel süreçte örgütsel adalet algısı, dağıtımsal adalet ve işlemsel adalet olarak iki boyutta incelenmiş̧ir. Dağıtımsal adalet, örgüt içi kaynakların adilane bir şekilde paylaştırılması olarak tanımlanmış (Lind, 2001); işlemsel adalet ise kaynakları elde etme ve paylaşma sürecindeki adil yaklaşım olarak ifade edilmiştir (Harris, Lievens, \& Van Hoye, 2004). Ancak literatürde bu iki boyuttan farklı bir boyutun da bulunduğu ve yöneticilerin kaynakları dağıtma sürecinde aldıkları kararların çalışanlarda davranışsal etkilere yol açtığı görüşü de vardır (Bies \& Shapiro, 1988). Yöneticilerin, kaynak edinimi ve dağııımı sürecinde aldıkları kararlarda çalışanlara karşı takındıkları tutum ve davranışlar ile çalışanların, yönetici ve diğer çalışanlara karşı tutum ve davranışları da etkileşimsel adalet olarak adlandırılmaktadır (McFarlin \& Sweeney, 1992). Özetle literatürde örgütsel adalet kavramı, dağıtımsal (kaynakların dağıtımı), işlemsel (kaynak dağıtım süreci) ve etkileşimsel (kaynak dağıtım sürecindeki karşılıklı iletişim) olarak sıralanabilen boyutlarda incelenmiştir.

Okul, örgütsel adaletin yoğun olarak hissedildiği kamusal alanlardandır. Okulda öğretmenlerin performans ve çalışma verimini etkileyebilecek bir önemde sahip olan örgütsel adaletin tesis edilememesi, öğretmenlerin birbirlerine ve okula karşı güven duygusu ile tutum ve davranışlarını olumsuz yönde etkileyecektir (Zainalipour, Fini, \& Mirkamali, 2010). Öğretmenin çalıştığı kuruma güvenmemesi, gerek derslerde gerekse okul içi iletişim süreçlerinde bilgi birikimi ve deneyimini kullanmaması anlamına gelmektedir. Böylesi bir iletişimsizlik ortamının, kolektif takım çalışmasını gerektiren okul gibi sosyal örgütlerde, örgütsel çözülme, işe yabancılaşma veya iş terki gibi çeşitli olumsuzluklara yol açacağı söylenebilir (Altahayneh, Khasawneh, \& Abedalhafiz, 2014; Colquitt vd., 2001).

Din, doğası gereği adalet kavramını içerisinde barındıran ve toplumsal adaletin her kurumsal yapıda olması gerektiğini vurgulayan bir olgudur. Dinin hak ve özgürlükleri gözeten doğası gereği tarihsel olarak din temelli toplumsal yapılar kaynağını Tanrısal emir ve yasaklardan alan bir adalet sistemini kullanagelmiş; bu adalet anlayışı zamanla demokratik değerleri içselleştirip kaynağını halkın ihtiyaç ve yaşantısına göre belirleyen bir yapıya kavuşmuştur (Colquitt, Greenberg, \& Zapata-Phelan, 2005). Günümüz adalet anlayışı, din temelli uygulamaları göz ardı etmemiş; toplumsal düzenin köklerine etki eden dini değer ve ilkeleri kullanmıştır. Dinin bu denli önemli bir kurgusala zemine sahip olması, toplumda dine ve din adamlarına ya da din eğitimi ile uğraşan uzmanlara karşı bir olumlu izlenim yaratımını 
desteklemiştir. Toplumda oluşan bu izlenimin bir sonucu olarak din adamlarının veya din eğitimi alanında uzmanlaşan profesyonellerin, doğal olarak hak ve hukuku gözeteceği ve diğerleri ile ilişkilerinde adil davranacağı inancı gelişmiştir (Greenberg \& Colquitt, 2013). Din eğitimcisine atfedilen yaygın inanç, bu çalışmanın gerçekleştirilmesindeki temel motivasyon kaynaklarındadır.

Okullar, farklı kaynakların girdi olarak kullanıldığı açık sistemlerdir. Bu kaynakları dengeli bir şekilde dağıtma görevi çoğu durumda okul yöneticisinin sorumluluğundadır. Okul yöneticisinin kaynak edinimi ve dağıtımı sürecinde adil davranması, okulda örgütsel adalet algısının yönelimini belirlemesi açısından önemlidir (Polat \& Celep, 2008). Öğretmenler, formel ve enformel ilişkiler ile yöneticinin kaynak edinimi ve dağıtımı sürecine etki edebilir ve bu sürecin adil olup olmadığını denetleyebilir. Böylesi bir durumda, toplumda genel kabul görmüş etik kod ve değerleri içselleştirdiğine inanılan din kültürü ve ahlak bilgisi (DKAB) öğretmenlerinin bir danışma makamı veya bir otorite gibi algılanması, okul kaynaklarının edinim ve dağıtımını da etkilemektedir. Buna karşın, aldıkları dini eğitim gereği, DKAB öğretmenlerinin de okul içindeki uygulamalara karşı bir adalet düşüncesinin olması ve bu adaletin okuldaki her çalışan için eşitçe bölüşülmesini düşünmesi de olasıdır. DKAB öğretmenlerinin, diğer alanlardaki öğretmenlerden farklı olarak din temelli adalet anlayışına yönelik özel alan bilgilerinin olması, bu alan bilgisine dayanarak örgütsel kaynakların edinim ve dağıtımına ilişkin okul içinde daha baskın bir eleştiri yapmalarına yol açmaktadır. DKAB öğretmenlerinin, örgütsel adalet algılarının diğer alanlardaki öğretmenlere göre farklılaştığı anlayışının okul içinde yaygın bir kanı olarak belirmesine yol açmıştır. Bu durum, çalışmanın ikincil motivasyon kaynağıdır.

Örgütsel adalet, farklı kavramlarla etkileşim halinde olan oldukça dinamik bir kavramdır. Literatürde özellikle bağlıık, yabancılaşma, vatandaşıı, özdeşleşme gibi kavramlar ile örgütsel adalet kavramı arasındaki ilişkilere yönelen çok sayıda araştırma vardır. Örgütsel adaletin etkileşimde olduğuna inanılan başka bir değişken de iş doyumu kavramıdır.

\section{İ̧ Doyumu Kavramı}

Toplumun daha üretken, sağlıklı ve mutlu olması, çalışanların işlerinden daha fazla doyum sağlamalarına bağlıdır. İş doyumu, çalışanların ihtiyaçlarının karşılanması ve iş ortamının iyileştirilmesi (Başaran, 2004), çalışanların istekleri ile iş yerinin ona sundukları arasındaki tutarlıık (Davis, 1988) olarak tanımlanabilir. Aynı işi yapsalar dahi iki çalışanın işe yönelik farklı beklentiler içinde olması, iş doyum düzeylerini etkileyebilir; bu noktada iş doyumunun, çalışanların beklentilerinden etkilendiği söylenebilir (de Bustillo Llorente \& Macias, 2005). Beklentiler, çalışanın işe yönelik algısı ile duygu durumlarının bir yansımasıdır. İş doyumu, çalışanın işini ve işi ile ilgili deneyimlerini öznel olarak değerlendirmesi neticesinde hissettiği memnuniyet halidir (Spector, 1985). Vroom'un beklenti kuramı gereği, iş doyumu, bir çalışanın hak ettiğini düşündüğü şeyler ve aldığı şeyler arasındaki farkın bir sonucudur (Mobley, 1977; Vroom, 1962). İ̧ yerinde hak ettiğine inandığı kazanımları elde edemeyen çalışan, iş doyumsuzluğu hissetmektedir (Wanous, Reichers, \& Hudy, 1997). Tanımlardan hareketle iş doyumu, çalışanın beklentilerinin karşılanma derecesi sonucu yaşadığı öznel bir süreçtir.

İ̧ doyumu, çevre (çalışma ortamı vb.), kişisel (karakter, davranış vb.) ve demografik (cinsiyet, yaş vb.) olarak sınıflandırılabilen oldukça çeşitli unsurlar tarafından etkilenen dinamik ve etkileşimli bir kavramdır (Crossman \& Harris, 2006). Öğretmenlerin iş doyumu ise gerek öğretim ortamı gerek okul içindeki diğer beklentilerin karşılanması ile ilişkili duygusal süreçleri içermektedir. Öğretim ortamında öğretmenin, öğrencilerden beklediği öğrenme durumları ve kendi öğretim sunumu arasındaki fark, öğretim kaynaklı iş doyumudur. Burada öğretmen, öğrenciye kazandırdığı ve kazandıramadığı davranışların bir karşılaştırmasını yapar ve eksikliklerini belirler; eksiklikler giderek öğretmenin iş doyumunun azalmasına neden olurken, öğrencilerin öğrenmeye karşı istekli olmaları iş doyumunu olumlu yönde etkiler 
(Zembylas \& Papanastasiou, 2005). Bununla birlikte, günlük işlerin sıradanlaşması, öğrencilerdeki disiplin sorunları, meslektaşlar ile kurulan iletişimde yaşanan sorunlar, yöneticilerin çalışmalarını takdir etmemesi gibi farklı etkenler de okul içinde öğretmen iş doyumunu etkileyebilmektedir (Klassen \& Chiu, 2010). İş doyumsuzluğu yaşayan öğretmenler, duygusal çatışma ve hayal kırıklıkları yaşamakta ve özsaygıları ile benlik algılarında önemli sorunlarla karşılaşabilmektedirler (Hülsheger, Alberts, Feinholdt, \& Lang, 2013; Skaalvik \& Skaalvik, 2011).

Öğretmenlerin iş doyumu yalnızca okul içi öğretim ve ilişkilerden etkilenmez; aynı zamanda mesleki özerklikte yaşanan sorunlar, kıt kaynakların verimli kullanılmaması, aldıkları ücret ve maaşların yetersizliği, eğitim sisteminde yaşanan anlık değişimler, veli baskısı, merkezi sınav sistemlerine dayalı değerlendirme sistemi, medyada veya eğitimle ilgili olmayan kesimler tarafından yapılan eleştiriler gibi pek çok etken, iş doyumunu etkilemektedir (Baltaci, 2017; Klassen \& Chiu, 2010; Koedel, Li, Springer, \& Tan, 2017; Ololube, 2006; Scott \& Dinham, 2003). İş doyumunu olumsuz etkileyen diğer faktörler arasında: iş yükü, işe ilişkin beklentilerin fazla olması, okul yönetiminin uyguladığı baskı ve denetim, yönetimsel iş ve işlemler ile çeşitli bürokratik engeller, kişisel gelişim veya kariyer imkânlarındaki sınırlılık, toplumda mesleğin itibarının düşük olması gibi nedenler sıralanabilir (Brown \& Peterson, 1993; Thompson, McNamara, \& Hoyle, 1997; Zembylas \& Papanastasiou, 2005). Bunun yanında öğretmenlerin medeni hali, cinsiyeti, yaşı, mesleki kıdemi ve çocuk sahibi olması gibi demografik değişkenlerin de iş doyumunu çeşitli şekillerde etkilediğine dair faklı araştırmalar vardır (Bilgiç, 1998; Koustelios, 2001; Okpara, 2004).

Öğretmenlik, diğer meslek gruplarından farklı olarak öğrencilerle çalışmayı ve onları toplum beklentilerine göre yetiştirmeyi amaçlar. Bu noktada toplumun belirli bir alan farkı gözetmeksizin tüm öğretmenlere eşit şekilde yaklaştığı (Szeto, 2015); ancak din gibi ayrıcalıklı bir olguyu öğrencilere kazandırmakla görevli öğretmenlere karşı farklı bir algısının olduğu (Martin, 2018) bilinmektedir. Bu sosyal etki din alanında çalışan öğretmenlerin, aynı zamanda o dinin bir temsilcisiymiş gibi algılanmasına yol açmaktadır (Shariff, Willard, Andersen, \& Norenzayan, 2016). DKAB öğretmenlerinin böylesi bir sosyal etkiyi yönetebilmesi çoğunlukla işe ve okula karşı olumlu yaklaşım içinde olması ile mümkün olabilir. Hangi alan öğretmeni olduğuna bakılmaksızın tüm öğretmenlerin iş doyumlarının yüksek olması, öğretmenlerin verdikleri eğitim ve öğretimin kalitesi için önemlidir. Ancak DKAB öğretmenleri özelinde değerlendirildiğinde, toplumun beklentilerini karşılayacak din eğitiminin sağlanması ve din eğitiminin kalitesinin arttırılmasında, öğretmenlerin sahip olduğu iş doyumu özel bir öneme sahip olmaktadır. DKAB öğretmenleri özelinde yapılan araştırmalarda iş doyumunun veli, öğrenci, meslektaş ve yöneticiler ile iyi ilişkiler kurulması durumunda yüksek olduğu; buna karşın fazla iş yükü, düşük ücret ve baskıcı yönetim anlayışı gibi etkenlerin iş doyumunu azalttığı belirlenmiştir (Gamero Burón \& Lassibille, 2016; Michaelowa, 2002). Özetle DKAB öğretmenlerinin iş doyumu, bireysel ve örgütsel unsurlar tarafından belirlenmektedir. Örgütsel unsurlar: öğretmenin iş güvenliği, özlük hakları, maaş ve ücret gibi maddi kazanımlar gibi yaşamsal ihtiyaçları sağlamaya dönük unsurlardır (Somech \& Drach-Zahavy, 2000). Buna karşın bireysel unsurlar: başkaları tarafından tanınma ve takdir edilme, başarılı olma, diğerlerinin saygı duyması, örnek bir öğretmen olarak gösterilme, öz saygı ve kendine güven gibi çoğunlukla ikincil ihtiyaçları sağlamaya yöneliktir (Griffith, 2004; Skaalvik \& Skaalvik, 2011).

İ̧ doyumu ve örgütsel adalet kavramları birbirlerini etkileyen dinamik kavramlardır. Okul içinde yaşanan adaletsizliklerin öğretmen performansını ve çalışma isteğini düşürdüğü, adaletsiz uygulamaların artması halinde ise iş terkinin yaşandığı, bu noktada öğretmenlerin adaletsizliğe sebep olduklarını düşündükleri kişi ve kurumlara karşı misilleme yapabilecekleri bildirilmektedir (Folger \& Cropanzano, 1998). Örgütsel adaletin önemli bir iş doyumu kaynağı olması; iş doyumunun, çalışanların bilişsel, duygusal ve davranışsal olarak iyi ve tutarlı olmasına bağlı olduğu gerekçesi ile öğretmenlerin iş doyumlarının belirlenmesi, eğitim 
sistemi içindeki eksiklerin ortaya çıkarılması önemlidir. Örgütsel adalet, örgüt kaynaklarının edinim ve dağıtımda adil ve eşit olunması ilkesini gerektirir; adaletin sağlanamadığı bir örgütte çalışanların iş yönelik tutum ve davranışlarında olumsuz değişimler görülmektedir (Moorman, Niehoff, \& Organ, 1993). Özetle okullarda adil uygulamaların desteklenmesi ile öğretmenlerin memnuniyetleri ile iş doyumları arttırılacak ve öğretmenlerin, okulun hedeflerine ulaşmasını sağlayıcı bir iş performansına ulaşması sağlanacaktır. Literatürde örgütsel adalet ile iş doyumuna yönelik farklı çalışmalar bulunmaktadır (Bakhshi, Kumar, \& Rani, 2009; Imran, Majeed, \& Ayub, 2015; Leung, Smith, Wang, \& Sun, 1996; López-Cabarcos, MachadoLopes-Sampaio-de Pinho, \& Vázquez-Rodríguez, 2015; Moorman vd., 1993; Nadiri \& Tanova, 2010; Ouyang, Sang, Li, \& Peng, 2015). Öğretmenlerin okullardaki adalet anlayışının iş doyumlarına etkisini araştıran çeşitli çalışmalar vardır (Altahayneh vd., 2014; DiPaola \& Tschannen-Moran, 2014; Khany \& Tazik, 2016; Nordhall \& Knez, 2018; Ostroff, 1992; Zainalipour vd., 2010). Bu araştırmalarda okullarda görülen adilane uygulamaların iş doyumunu yükselttiği; adaletin sağlanamadığı okulların, öğretmenlerde iş doyumsuzluğu, iş terki, kaytarma ve çeşitli iç karışıkıklar yaşadığı belirlenmiştir. Benzer araştırmaların Türkçe literatürde de yapıldığı ve yurtdışı literatürde belirlenen sonuçlara ulaşıldığı görülmektedir (Baltaci, 2017; Eker, 2006; Özer \& Urtekin, 2007; Polat \& Celep, 2008; Sezgin, 2005; Yelboğa, 2012; Yildirim, 2007). Ancak literatürde din eğitimi alanında çalışan öğretmenlerin örgütsel adalet algıları ile iş doyum düzeylerini konu edinen bir çalışmaya rastlanılamamıştır.

\section{Araştırmanın Amacı ve Önemi}

Toplumun geleceğine yön veren ve toplumdaki özellikli konumu nedeniyle din ve din eğitimi alanında çalışan öğretmenlerin iş doyum düzeyleri ile okullardaki adalet algılarını belirlemek bu çalışmanın temel amacını oluşturmaktadır. Elbette 'adalet' kavramının yeni nesillere öğretimi ve içselleştirilmesi, tüm öğretmenleri ilgilendirse de yürürlükte olan yeni DKAB öğretim programında özgün ve disiplinlerarası olan söz konusu kavramın, çoğunlukla din eğitimi dersleri ile eşlendiği görülmektedir. Adalet kavramından farklı olarak örgütsel adalet ise okul içindeki eylem ve uygulamalarda hak ve hukuk kurallarının gözetilmesidir. Bu yönü ile diğer öğretmenler gibi DKAB öğretmenlerinin, çalıştıkları okullarda örgütsel işleyiş hakkında bilgi sahibi olmaları kaçınılmazdır. Ancak adalet kavramını yeni nesillere iletmekle görevli olan DKAB öğretmenlerinin, okullardaki örgütsel adalet yaklaşımına duyarsız kalması söz konusu olamaz. Bu noktada DKAB öğretmenlerinin örgütsel adalet algısının belirlenmesi, onların derslerde anlattıkları adalet olgusunu, günlük hayatın içine taşıma potansiyellerini de açığa çıkaracaktır. Bununla birlikte, okul içinde alınan kararlar ile kaynakların kullanımı noktasında hak ve hukuk kurallarına riayet edilmesi gerektiği evrensel bir ilkedir. Ayrıca literatürde yer alan farklı çalışmalarda okullarda alınan kararlar ve kaynak kullanımında hak ve hukuk dışı durumların yaşanabildiğine yönelik bulgular yer almaktadır (Baltacı, 2017; Cemaloğlu ve Kılınç, 2012). Böylesi bir durum okul içindeki tüm çalışanlar tarafından az ya da çok bilinmekte ve adilane uygulamaların nicelik olarak azalması örgütte kargaşa yaratmaktadır. Konunun incelenmesi ile özelde DKAB öğretmenlerinin örgütsel adalet düzeyleri belirlenecek ve bunun iş doyumlarını ne derece etkilediği incelenecektir. Okullarda yaşanan aktif kaynak edinim ve dağıtım süreçlerindeki adilane uygulamaları gözler önüne serme çabasında olan bu çalışma, ayrıca DKAB öğretmenlerinin yetiştirilmesi ve onlara yönelik diğer hizmetiçi faaliyetleri geliştirilmesi noktasında politika belirleyiciler için veri sunma gayretindedir. Literatürde DKAB öğretmenlerinin örgütsel adalet algısı ve iş doyum düzeyleri arasındaki etkileşimi belirlemeye odaklanan bir çalışmanın belirlenememiş olması bu çalışmanın öncü karakterine vurgu yapmaktadır. Araştırmanın konuya ilişkin yeni bulguları sunma çabası içinde olması nedeniyle literatürdeki önemli bir boşluğu kapatması ve ileride yürütülecek araştırmalar için yeni çalışma alanı oluşturması beklenmektedir. 
Bu araştırma, DKAB öğretmenlerinin, iş doyumları ile örgütsel adalet algılarının belirlenmesi amacıyla yürütülmüştür. Ayrıca örgütsel adaletin, iş doyumu ile ilişkisi de çalışma kapsamında belirlenecektir. Çalışma kapsamında aşağıdaki soruların cevabı aranmaya çalışılacaktır:

1. $D K A B$ öğretmenlerinin örgütsel adalet algıları ve iş doyum düzeyleri nedir?

2. $D K A B$ öğretmenlerinin cinsiyet, eğitim durumu ve mesleki kıdemlerine göre örgütsel adalet algıları farklılaşmakta mıdır?

3. DKAB öğretmenlerinin cinsiyet, eğitim durumu ve mesleki kıdemlerine göre iş doyumları farklılaşmakta mıdır?

4. DKAB öğretmenlerinin iş doyumları ile örgütsel adalet algıları arasında anlamlı bir ilişki var mıdır?

\section{YÖNTEM}

\section{Desen}

Bu çalışma, DKAB öğretmenlerinin örgütsel adalet algısı ve iş doyum düzeyleri arasındaki ilişkiyi saptamak amacıyla nicel araştırma yöntemlerinden ilişkisel tarama modelinde tasarlanmıştır. İlişkisel tarama modelinde en az iki değişken arasındaki ilişkinin yoğunluğu, yönelimi, türü, seviye ve eğilimi belirlenmesi amaçlanır (Vogt, 2006). DKAB öğretmenlerin iş doyumu ve örgütsel adalet algı düzeyini belirlenmesi, bu araştırmanın ilişkisel tarama modelinde olmasını gerektirmiştir.

\section{Evren ve Örneklem}

Araştırmanın hedef evrenini, İstanbul İlinin 39 ilçesinde görev yapan 3396 DKAB öğretmeni oluşturmaktadır. Evrenden \%95'lik güven düzeyi ile \%5'lik güven aralığı dikkate alınarak oranlı küme örnekleme yöntemiyle belirlenen örneklem büyüklüğü 345'tir. Oranlı küme örnekleminde her ilçe bir küme olarak kabul edilmiş; her bir kümeden kaç DKAB öğretmeninin seçilmesi için ise tabaka ağırlığı=örneklem büyüklüğü/evren büyüklüğü formülü kullanılmıştır. Araştırma kapsamında katılımcılara (DKAB öğretmenleri), 550 ölçek gönderilmiş, 411'i geri dönmüştür. Bu ölçeklerden 17'si eksik veya hatalı doldurma, 5'i de aykırı değerler nedeniyle analize alınmamıştır. Belirlenen örneklem büyüklüğünü karşılayan ve hedef evrenin \%11,5'ini oluşturan 389 ölçek analize dâhil edilmiştir. Örneklemde yer alan katılımcılara ilişkin demografik bulgular Tablo 1'de görülmektedir.

Tablo 1

Katılımcılara iliş̧kin Demografik Bilgiler

\begin{tabular}{|c|c|c|c|c|}
\hline Değişkenler & Alt Kategoriler & $\mathbf{N}$ & $\%$ & Toplam \\
\hline \multirow{2}{*}{ Cinsiyet } & Erkek & 202 & 51.93 & \multirow{2}{*}{389} \\
\hline & Kadın & 187 & 48.07 & \\
\hline \multirow{2}{*}{ Eğitim Durumu } & Lisans & 296 & 76.09 & \multirow{2}{*}{389} \\
\hline & Yüksek Lisans & 93 & 23.91 & \\
\hline \multirow{3}{*}{ Mesleki Kıdem } & 1-5 yıl & 109 & 28.02 & \multirow{3}{*}{389} \\
\hline & 6-10 yıl & 159 & 40.87 & \\
\hline & 11 yıl ve üstü & 121 & 31.11 & \\
\hline
\end{tabular}

Tablo 1 incelendiğinde, katılımcıların \% 51,93'ü ( $N=202$ ) erkektir ve \%76,09'u ( $N=296)$ lisans düzeyinde eğitim almıştır. Ayrıca katılımcıların \%86,63'ü kamu okullarında çalışmakta ve \%40,87'sinin mesleki kıdemi 6-10 yıl arasında değişmektedir. 


\section{Veri Toplama Araçları}

Araştırma kapsamında toplanan veriler üç farklı ölçek ile edinilmiştir. Ölçme aracı olarak ilk bölümde araştırmacı tarafından hazırlanmış olan DKAB öğretmenlerinin demografik özelliklerini içeren "Kişisel Bilgi Formu", ikinci bölümde adalet algılarını ölçmek için kullanılan "Örgütsel Adalet Algısı Ölçeği” ve iş doyum düzeylerini belirlemek için ise "Minnesota İş Doyumu Ölçeği" kullanılmıştır.

Örgütsel Adalet Ölçeği: Bu çalışmada, Niehoff ve Moorman (1996) tarafından geliştirilen ve Polat (2007) tarafından Türk kültürüne uyarlanan "Örgütsel Adalet Ölçeği” kullanılmıştır. Üç faktöre ayrılan likert tipli ölçekte maddeler: “(1) Kesinlikle Katılmıyorum ile (5) Tamamen Katılıyorum” arasında beş aralıklı olarak derecelendirilmiştir. Ölçekten alınan puan arttıkça, örgütsel adalete ilişkin algı da olumlu bir şekilde artış göstermekte; tersinde ise olumsuz örgütsel adalet algısı ortaya çıkmaktadır. Bu çalışma kapsamında kullanılan ölçeğin iç tutarlık katsayısı dağıtım adaleti için .86, işlemsel adalet için .91, etkileşim adaleti için .83 ve ölçeğin geneli için .87 olarak bulunmuştur. Araştırmada beşli derecelendirme ölçeğine uygun olarak elde edilen ağırlıklı ortalama puanların derecelendirilmesi ve yorumlanması için: 1.00-2.33 Düşük düzeyde örgütsel adalet algISI, 2.33-3.66=Orta düzeyde örgütsel adalet algıSı ve 3.66-5.00=Yüksek düzeyde örgütsek adalet algısı olarak yorumlanmaktadır. Örgütsel adalet ölçeğinin yapı geçerliğini (construct validity) belirlemek ve üç faktörlü bir yapıya sahip olup olmadığını saptamak amacıyla ölçeğin faktör yapısı "Temel Bileşenler Faktör Analizi" kullanılarak ve faktör sayısına herhangi bir sınırlama getirilmeksizin incelenmiştir. Faktör analizi sonuçları, Örgütsel Adalet Ölçeğinin tüm maddeleri için eigen değerinin (özdeğer) 1 in üstünde olan üç faktörde toplandığı belirlenmiştir. Analiz sonucunda bu üç faktörün açıkladığı varyans miktarı \%61.3'tür. Bu araştırma kapsamında ölçeğin yapı geçerliğini sınamak için doğrulayıcı faktör analizi (DFA) kullanılmıştır. DFA sonucunda gizil değişkenler ile gözlenen değişkenlerin farklılaşma derecesini belirleyen t testi değerlerinin de .05 seviyesinde anlamlı olduğu belirlenmiştir. DFA sonucunda ölçeğin iyi bir uyum gösterdiği belirlenmiştir [(X2[258]= 512.256, $p<.01)$, $\mathrm{X} 2 / \mathrm{sd}=1.98, \mathrm{RMSEA}=.054, \mathrm{GFI}=.92, \mathrm{IFI}=.93, \mathrm{NFI}=.93, \mathrm{NNFI}=.92$ ve $\mathrm{CFI}=.91]$. DFA sonuçlarında gözlenen ve beklenen model arasındaki uyum derecesinin $(X 2 / s d=1.98)$, ölçeğin iyi bir uyum gösterdiğini belirlemektedir. Buna göre Örgütsel adalet ölçeğinin, bu araştırmada incelenen konuyu ölçebilecek yeterlik, geçerlik ve güvenirlikte olduğu sonucuna varılmıştır.

İ̧ Doyumu Ölçeği: Araştırmada Weiss, Dawis, England \& Lofquist (1967) tarafından geliştirilmiş olan ve Baycan (1985) tarafından Türkçeye uyarlanan Minnesota İş Doyum Ölçeği kullanılmıştır. İçsel ve dışsal iş doyumu olarak iki faktörden oluşan ölçek, 5'li likert tipi puanlamaya sahip 20 maddeden oluşmaktadır. Ölçekte bulunan bireysel doyum faktörü: etkinlik, bağımlı olma, tutarsızlık, sosyal statü, ahlak, güvenlik kaygısı, sosyal çalışmaya yatkınlık, yetki gücü, yeteneklerini kullanma, sorumluluk, yaratıcı düşünce ve başarı duygusu olarak belirlenen 12 sorudan oluşmaktadır. Örgütsel doyum faktörü ise, yönetsel denetim, yönetsel karar verme, kurum politikası, çalışma koşulları, maddi kaynak politikası (ücret ve maaş vb.), terfi, takım çalışmasına yatkınlık ve takdir edilme olarak belirlenen 8 sorudan oluşmaktadır. Ölçekteki maddeler (1) hiç memnun değilim ile (5) çok memnunum arasında değişen aralıklarla puanlanmaktadır. Elde edilen puanlar; 1.00-2.33 Düşük düzeyde iş doyumu, 2.33-3.66=Orta düzeyde iş doyumu ve 3.66-5.00=Yüksek düzeyde iş doyumu olarak yorumlanmaktadır. Bu çalışmada kullanılan ölçeğin iç tutarlık katsayısı bireysel doyum için .86, örgütsel doyum için .79 ve toplam doyum için .83 olarak hesaplanmıştır.

İs Doyumu Ölçeğinin geçerliği, yapı geçerliği (construct validity) ve uyum geçerliği (concurrent validity) yöntemleri kullanılarak saptanmaya çalışılmıştır. İş Doyumu ölçeğinin yapı geçerliğini belirlemek ve iki boyutlu bir yapıya sahip olup olmadığını saptamak amacıyla ölçeğin faktör yapısı "Temel Bileşenler Faktör Analizi" kullanılarak ve faktör sayısına herhangi bir sınırlama getirilmeksizin incelenmiştir. Faktör analizi 
sonuçları, İ̧̧ Doyumu Ölçeğinin tüm maddeleri için eigen değeri 1 in üstünde olan iki faktörde toplandığı saptanmıştır. Analiz sonucunda bu iki faktörün açıkladığı varyans miktarı \%68.4'tür. Bu araştırma kapsamında ölçeğin yapı geçerliğini sınamak için doğrulayıcı faktör analizi (DFA) kullanılmıştır. DFA sonucunda ölçeğin iyi bir uyum gösterdiği belirlenmiştir [(X2[314] $=593.194, p<.01), X 2 / s d=1.88, R M S E A=$ $.052, \mathrm{GFI}=.94, \mathrm{IFI}=.95, \mathrm{NFI}=.95, \mathrm{NNFI}=.94$ ve $\mathrm{CFI}=.93]$. DFA sonuçlarında gözlenen ve beklenen model arasındaki uyum derecesinin $(\mathrm{X} 2 / \mathrm{sd}=1.88)$, ölçeğin iyi bir uyum gösterdiğini belirlemektedir. İş Doyumu ölçeğinin uyum geçerliği ise Cohen ve Williamson (1988) tarafından geliştirilen ve Türkçe uyarlaması Baltaş (1998) tarafından yapılan, "Algılanan İş Stresi Ölçeği" kullanılarak yapılmıştır. İş Doyumu Ölçeği ile Algılanan İş Stresi Ölçeği puanları arasındaki korelasyonlar hesaplanmıştır. Daha sonra, son yıllarda özellikle iş doyumu ile tükenmişlik düzeyleri arasındaki ilişkileri inceleyen araştırma bulgularından hareketle, Ölçeğin, "Maslach Tükenmişlik Envanteri" Ölçeğinin alt ölçekleriyle ilişkileri araştırılmıştır. İş Doyumu Ölçeği ile Maslach Tükenmişlik Envanteri ve Algılanan İş Stresi Ölçeğinin alt Ölçekleri arasında elde edilen tüm korelasyon katsayıları anlamlı düzeydedir. Böylelikle araştırmada kullanılan İş Doyum ölçeğinin, incelenen konuyu ölçebilecek geçerlik ve güvenirlikte olduğu sonucuna varılmıştır.

Araştırma kapsamında katılımcıların gönüllü olarak araştırmaya katılmaları ilkesi benimsenmiş ve katılımcılara, araştırmacı tarafından araştırmanın amacı, önemi ve kapsamı hakkında bilgiler verilmiştir. Araştırma hakkında bilgilendirilen katılımcılardan ölçme araçlarındaki ifadeleri dikkatlice okumaları ve kendilerine göre en doğru olan seçeneği işaretlemeleri istenmiştir. Ölçekler için her bir katılımcıya iki hafta süre verilmiştir. İlgili süre sonucunda doldurulan ölçekler, ulaşılabilirlik koşulları doğrultusunda araştırmacı tarafından bizzat okullar ziyaret edilerek toplanmıştır. Verilerin toplandıktan sonra uç değerler ve hatalı doldurmalar ayıklanmış ve ana uygulamanın analiz süreci başlatılmıştır.

\section{Verilerin Analizi}

Ölçme araçlarıyla elde edilen veriler, SPSS programıyla analiz edilmiştir. Parametrik testler uygulanmadan

önce, bu testlerin temel varsayımları sorgulanmıştır. Öncelikle çalışma grubunun normal dağııım gösterip göstermediği incelenmiştir. Bu çalışmada yapılan normal dağılım analizleri skewness (çarpıklık)= -.456; kurtosis (basıklık)= .794 olarak bulunmuş ve çalışma grubunun normal dağılım gösterdiği anlaşılmıştır. Parametrik testlerin diğer varsayımı olan varyansların homojenliği Levene testi ile belirlenmiş; bağımsız değişkenlere (cinsiyet, eğitim durumu meslek kıdem ve okul türü) göre yapılan analizde anlamlılık (p) değerleri .05'ten yüksek çıkmıştır. Elde edilen bu bulgulara dayanarak parametrik testlerin kullanılması uygun görülmüştür. Demografik değişkenlerin çözümlenmesinde ve bağımlı değişkenlerle olan ilişkilerinin belirlenmesinde: cinsiyet, eğitim durumu ve okul türü değişkenleri için t-testi ile mesleki kıdem değişkeni için tek yönlü varyans analizi yapılmıştır. Ayrıca değişkenler arası ilişkiyi belirleyebilmek için veri setine korelasyon ve doğrusal regresyon analizi uygulanmıştır. Varyans geçerlikleri Levene testiyle, varyans farklılıkları Bonferroni testiyle ve ilişkisel karşılaştırmalar ise Pearson ( $r$ ) katsayısı ile ölçülmüştür. Tüm bulgular, .05 ve. 01 anlamlılık düzeyi temelinde yorumlanmıştır. Araştırmada korelasyon katsayısının mutlak değer olarak: .90-1.0 arası çok yüksek; .70-.89 arası yüksek; .50-.69 arası orta; .30-.49 arası düşük ve .30-.01 ise çok düşük ilişki olarak belirlenmiştir (Croux \& Dehon, 2010).

\section{BULGULAR}

Bu bölümde DKAB öğretmenlerinin örgütsel adalet algıları ve iş doyum düzeylerine ilişkin betimsel analiz sonuçlarına; örgütsel adalet ve iş doyumunun araştırmanın bağımsız değişkenleri olan cinsiyet, eğitim durumu ve meslek kıdeme göre farklılaşma derecesine; DKAB öğretmenlerinin örgütsel adalet algılarının iş doyum düzeyleri ile ilişki düzeyine yönelik korelasyon ve doğrusal regresyon analizi sonuçlarına yer 
verilmiştir. DKAB öğretmenlerinin örgütsel adalet algılarına ve iş doyum düzeylerine ilişkin betimsel analiz sonuçları Tablo 2' de sunulmuştur.

Tablo 2

Katılımcıların Örgütsel Adalet Algıları ve Iş̧ Doyum Düzeylerine Iliş̧kin Betimsel Analiz Sonuçları

\begin{tabular}{llccc} 
Boyutlar & Alt Boyutlar & $\mathbf{N}$ & $\overline{\mathbf{X}}$ & ss \\
\multirow{3}{*}{ Örgütsel Adalet } & Dağıtımsal Adalet & 389 & 3.41 & .85 \\
& İşlemsel Adalet & 389 & 3.21 & .91 \\
& Etkileşimsel Adalet & 389 & 3.09 & .83 \\
\cline { 2 - 2 } & Genel Örgütsel Adalet Algısı & 389 & 3.24 & .86 \\
\cline { 2 - 2 } İş Doyumu & Bireysel İş Doyumu & 389 & 2.49 & .73 \\
& Örgütsel İş Doyumu & 389 & 2.13 & .69 \\
\cline { 2 - 2 } & Genel İş Doyumu & 389 & 2.31 & .71 \\
\hline
\end{tabular}

Tablo 2 incelendiğinde katılımcıların dağıtımsal ( $\bar{X}=3.41)$, işlemsel $(\bar{X}=3.21)$ ve etkileşimsel $(\bar{X}=3.09)$ adalet algısına 'çoğunlukla' sahip oldukları belirlenmiştir. Benzer şekilde katılımcılar, genel örgütsel adalet algısına da ( $\bar{X}=3.24)$ 'orta düzeyde' sahiptirler. Katılımcıların 'orta' düzeyde bireysel $(\bar{X}=2.49)$ ve 'orta düşük' düzeyde örgütsel ( $\bar{X}=2.13)$ iş doyumuna sahip oldukları saptanmıştır. Ayrıca katılımcıların genel iş doyumu seviyesi de 'orta düşük' düzeydedir ( $\bar{X}=2.31)$.

\section{Örgütsel Adalet Algısına ilişkin Bulgular}

Katılımcıların bağımsız değişkenlere göre örgütsel adalet algılarına ilişkin bulgular Tablo 3'te görülmektedir.

Tablo 3

Çeşitli Demografik Değişkenlere Göre Katılımcıların Örgütsel Adalet Algıları

\begin{tabular}{|c|c|c|c|c|c|c|c|c|}
\hline Alt Boyutlar & Değişkenler & Kategoriler & $\mathbf{N}$ & $\overline{\mathbf{x}}$ & ss & sd & $\mathbf{t}$ & $\mathbf{P}$ \\
\hline \multirow{4}{*}{ Dağıtımsal Adalet } & \multirow{2}{*}{ Cinsiyet } & Erkek & 202 & 3.23 & .93 & \multirow{2}{*}{387} & \multirow{2}{*}{4.16} & \multirow{2}{*}{$.001^{*}$} \\
\hline & & Kadın & 187 & 3.59 & .76 & & & \\
\hline & \multirow{2}{*}{ Eğitim Durumu } & Lisans & 296 & 3.22 & 1.07 & \multirow{2}{*}{387} & \multirow{2}{*}{3.25} & \multirow{2}{*}{$.002 *$} \\
\hline & & Lisansüstü & 93 & 3.60 & .63 & & & \\
\hline \multirow{4}{*}{ İşlemsel Adalet } & \multirow{2}{*}{ Cinsiyet } & Erkek & 202 & 3.09 & 1.17 & \multirow{2}{*}{387} & \multirow{2}{*}{2.47} & \multirow{2}{*}{$.013^{*}$} \\
\hline & & Kadın & 187 & 3.33 & .65 & & & \\
\hline & \multirow{2}{*}{ Eğitim Durumu } & Lisans & 296 & 2.93 & 1.36 & \multirow{2}{*}{387} & \multirow{2}{*}{3.89} & \multirow{2}{*}{$.003^{*}$} \\
\hline & & Lisansüstü & 93 & 3.49 & .46 & & & \\
\hline \multirow{4}{*}{ Etkileşimsel Adalet } & \multirow{2}{*}{ Cinsiyet } & Erkek & 202 & 2.95 & .93 & \multirow{2}{*}{387} & \multirow{2}{*}{3.16} & \multirow{2}{*}{$.009 *$} \\
\hline & & Kadın & 187 & 3.22 & .73 & & & \\
\hline & \multirow{2}{*}{ Eğitim Durumu } & Lisans & 296 & 2.77 & 1.07 & \multirow{2}{*}{387} & \multirow{2}{*}{5.50} & \multirow{2}{*}{$.001^{*}$} \\
\hline & & Lisansüstü & 93 & 3.41 & .59 & & & \\
\hline \multirow{4}{*}{$\begin{array}{c}\text { Genel Örgütsel Adalet } \\
\text { Algısı }\end{array}$} & \multirow{2}{*}{ Cinsiyet } & Erkek & 202 & 3.09 & 1.01 & \multirow{2}{*}{387} & \multirow{2}{*}{3.25} & \multirow{2}{*}{$.011^{*}$} \\
\hline & & Kadın & 187 & 3.38 & 0.71 & & & \\
\hline & \multirow{2}{*}{ Eğitim Durumu } & Lisans & 296 & 2.97 & 1.17 & \multirow{2}{*}{387} & \multirow{2}{*}{4.21} & \multirow{2}{*}{$.007^{*}$} \\
\hline & & Lisansüstü & 93 & 3.50 & .56 & & & \\
\hline
\end{tabular}

$*_{p}<.05$ 
Tablo 3'te katılımcıların cinsiyetleri ile genel örgütsel adalet algıları arasında anlamlı bir fark bulunmaktadır [t(387)=3.25; $\mathrm{p}<.05]$. Örgütsel adaletin dağıtımsal, işlemsel ve etkileşimsel alt boyutlarında kadınların (sırasıyla $\bar{X}=3.59 ; \bar{X}=3.33$ ve $\bar{X}=3.22$ ), erkeklere göre (sırasıyla $\bar{X}=3.23 ; \bar{X}=3.09$ ve $\bar{X}=2.95)$ örgütsel adalet algıları daha yüksektir. Genel örgütsel adalet düzeyinde kadınlar ( $\bar{X}=3.38)$, erkeklere göre ( $\bar{X}=3.09)$ daha yüksek düzeyde öz yeterlik algısına sahiptirler. Eğitim durumu, genel örgütsel adalet algısı ile anlamlı olarak değişmektedir $[\mathrm{t}(387)=4.21 ; \mathrm{p}<.05]$. Örgütsel adaletin dağıtımsal, işlemsel ve etkileşimsel alt boyutlarında lisansüstü seviyesinde eğitim alanların (sırasıyla $\bar{X}=3.60, \bar{X}=3.49$ ve $\bar{X}=3.41$ ), lisans seviyesinde eğitim alanlara göre (sırasıyla $\bar{X}=3.22, \bar{X}=2.93$ ve $\bar{X}=2.77$ ) örgütsel adalet algıları daha yüksektir. Genel örgütsel adalet algısında da lisansüstü seviyesinde eğitime sahip olanlar ( $\bar{X}=3.50)$, lisans seviyesinde eğitime sahip olanlara göre $(\bar{X}=2.97)$ daha yüksek düzeyde örgütsel adalet algısına sahiptirler. Tablo 4'te katılımcıların mesleki kıdemlerine göre örgütsel adalet algılarına ilişkin bulgular yer almaktadır.

Tablo 4

Mesleki Kıdeme Göre Katılımcıların Örgütsel Adalet Algıları

\begin{tabular}{|c|c|c|c|c|c|c|c|c|c|}
\hline Alt Boyutlar & & Mesleki Kıdem & $\mathbf{N}$ & $\overline{\mathbf{x}}$ & ss & sd & $\mathbf{F}$ & $\mathbf{p}$ & Anlamlı Fark \\
\hline \multirow{3}{*}{ Dağıtımsal Adalet } & 1 & 5 yıl ve altı & 109 & 3.05 & 1,02 & \multirow{3}{*}{$2 ; 386$} & \multirow{3}{*}{4.05} & \multirow{3}{*}{$.018^{*}$} & $1-2$ \\
\hline & 2 & 6-10 yıl & 159 & 3.46 & 0,89 & & & & $1-3$ \\
\hline & 3 & 11 yıl ve üstü & 121 & 3.72 & 0,64 & & & & $2-3$ \\
\hline \multirow{3}{*}{ İşlemsel Adalet } & 1 & 5 yıl ve altı & 109 & 3.01 & 1,09 & \multirow{3}{*}{$2 ; 386$} & \multirow{3}{*}{3.60} & \multirow{3}{*}{$.028 *$} & $1-2$ \\
\hline & 2 & 6-10 yıl & 159 & 3.26 & 0,89 & & & & $1-3$ \\
\hline & 3 & 11 yıl ve üstü & 121 & 3.36 & 0,75 & & & & $2-3$ \\
\hline \multirow{3}{*}{ Etkileşimsel Adalet } & 1 & 5 yıl ve altı & 109 & 2.93 & 0,94 & \multirow{3}{*}{$2 ; 386$} & \multirow{3}{*}{3.08} & \multirow{3}{*}{$.047^{*}$} & $1-2$ \\
\hline & 2 & 6-10 yıl & 159 & 3.08 & 0,82 & & & & $1-3$ \\
\hline & 3 & 11 yıl ve üstü & 121 & 3.26 & 0,73 & & & & $2-3$ \\
\hline \multirow{3}{*}{$\begin{array}{c}\text { Genel Örgütsel Adalet } \\
\text { Düzeyi. }\end{array}$} & 1 & 5 yıl ve altı & 109 & 3.00 & 1,02 & \multirow{3}{*}{$2 ; 386$} & \multirow{3}{*}{3.47} & \multirow{3}{*}{$.032 *$} & $1-2$ \\
\hline & 2 & 6-10 yıl & 159 & 3.27 & 0,87 & & & & $1-3$ \\
\hline & 3 & 11 yıl ve üstü & 121 & 3.45 & 0,71 & & & & $2-3$ \\
\hline
\end{tabular}

$* p<.05$

Tablo 4 incelendiğinde, katılımcıların mesleki kıdemleriyle örgütsel adalet algılarının anlamlı olarak değiştiği görülmektedir $[F(2 ; 386)=3.47 ; p<.05]$. Mesleki kıdem, dağıtımsal, işlemsel ve etkileşimsel adalet alt boyutlarında anlamlı bir farklılık göstermektedir $(p<.05)$. Örgütsel adaletin tüm alt boyutlarında ve genel örgütsel adalet algısı ile mesleki kıdemin alt grupları arasındaki fark incelendiğinde 11 yıl ve üstü mesleki kıdeme sahip olanların, 6-10 yıl ve 5 yıl ve altı yıl kıdeme sahip olanlara göre daha fazla; 6-10 yıl mesleki kıdeme sahip olanların da 5 yıl ve altı kıdeme sahip olanlara göre daha fazla örgütsel adalet algısına sahip olduğu belirlenmiştir. Mesleki kıdem arttıkça katılımcıların örgütsel adalet algıları da artmaktadır.

\section{İs Doyumuna ilişkin Bulgular}

Katılımcıların iş doyum düzeylerinin, bağımsız değişkenlerle farklılaşma durumu Tablo 5'te görülmektedir. 
Tablo 5

Çeşitli Demografik Değişkenlere Göre Katılımcıların İ̧ Doyum Düzeyleri

\begin{tabular}{|c|c|c|c|c|c|c|c|c|}
\hline Alt Boyutlar & Değiş̧kenler & Kategoriler & $\mathbf{N}$ & $\overline{\mathbf{x}}$ & ss & sd & $\mathbf{t}$ & $\mathbf{P}$ \\
\hline \multirow{4}{*}{$\begin{array}{l}\text { Bireysel İş } \\
\text { Doyumu }\end{array}$} & \multirow{2}{*}{ Cinsiyet } & Erkek & 202 & 2.34 & .87 & \multirow{2}{*}{387} & \multirow{2}{*}{3.94} & \multirow{2}{*}{$.021 *$} \\
\hline & & Kadın & 187 & 2.64 & .59 & & & \\
\hline & \multirow{2}{*}{ Eğitim Durumu } & Lisans & 296 & 2.31 & .67 & \multirow{2}{*}{387} & \multirow{2}{*}{4.32} & \multirow{2}{*}{$.017^{*}$} \\
\hline & & Lisansüstü & 93 & 2.67 & .79 & & & \\
\hline \multirow{4}{*}{$\begin{array}{l}\text { Örgütsel İş } \\
\text { Doyumu }\end{array}$} & \multirow{2}{*}{ Cinsiyet } & Erkek & 202 & 1.89 & .65 & \multirow{2}{*}{387} & \multirow{2}{*}{6.85} & \multirow{2}{*}{$.001^{*}$} \\
\hline & & Kadın & 187 & 2.37 & .73 & & & \\
\hline & \multirow{2}{*}{ Eğitim Durumu } & Lisans & 296 & 1.97 & .71 & \multirow{2}{*}{387} & \multirow{2}{*}{3.84} & \multirow{2}{*}{$.019^{*}$} \\
\hline & & Lisansüstü & 93 & 2.29 & .67 & & & \\
\hline \multirow{4}{*}{$\begin{array}{c}\text { Genel İş } \\
\text { Doyum Düzeyi }\end{array}$} & \multirow{2}{*}{ Cinsiyet } & Erkek & 202 & 2.12 & .76 & \multirow{2}{*}{387} & \multirow{2}{*}{5.38} & \multirow{2}{*}{$.003^{*}$} \\
\hline & & Kadın & 187 & 2.51 & .66 & & & \\
\hline & \multirow{2}{*}{ Eğitim Durumu } & Lisans & 296 & 2.14 & .69 & \multirow{2}{*}{387} & \multirow{2}{*}{4.08} & \multirow{2}{*}{$.021^{*}$} \\
\hline & & Lisansüstü & 93 & 2.48 & .73 & & & \\
\hline
\end{tabular}

$* p<.05$

Tablo 5 'te katılımcıların cinsiyetleri ile genel iş doyumları arasında anlamlı bir fark bulunmaktadır $[\mathrm{t}(387)=5.38 ; p<.05]$. İ̧̧ Doyumunun bireysel ve örgütsel alt boyutlarında erkeklerin ( $\bar{X}=2.34$ ve $\bar{X}=1.89)$, kadınlara göre ( $\bar{X}=2.64$ ve $\bar{X}=2.37)$ iş doyumları daha düşüktür. Genel iş doyum düzeyinde erkekler $(\bar{X}=2.12)$, kadınlara göre $(\bar{X}=2.51)$ daha düşük düzeyde iş doyumuna sahiptirler. Eğitim durumu, genel iş doyumu ile anlamlı olarak değişmektedir $[\mathrm{t}(387)=4.08 ; \mathrm{p}<.05]$. İş doyumunun bireysel ve örgütsel lisans seviyesinde eğitim alanların (sırasıyla $\bar{X}=2.31$ ve $\bar{X}=1.97$ ), lisansüstü seviyesinde eğitim alanlara göre (sırasıyla $\bar{X}=2.67$ ve $\bar{X}=2.29$ ) iş doyumları daha düşük seviyededir. Genel iş doyumu düzeyinde de lisans seviyesinde eğitime sahip olanlar ( $\bar{X}=2.14)$, lisansüstü seviyesinde eğitime sahip olanlara göre $(\bar{X}=2.48)$ daha düşük düzeyde iş doyumuna sahiptirler. Tablo $\sigma^{\prime}$ da katılımcıların mesleki kıdemlerine göre iş doyumlarına ilişkin bilgiler yer almaktadır.

Tablo 6

Mesleki Kıdeme Göre Katılımcıların Iş Doyumu Düzeyleri

\begin{tabular}{|c|c|c|c|c|c|c|c|c|c|}
\hline Alt Boyutlar & & sleki Kıdem & $\mathbf{N}$ & $\overline{\mathbf{x}}$ & ss & sd & $\mathbf{F}$ & p & Anlamlı Fark \\
\hline \multirow{3}{*}{ Bireysel İş Doyumu } & 1 & 5 yıl ve altı & 109 & 2,83 & 1,09 & & & & \\
\hline & 2 & 6-10 yıl & 159 & 2,47 & 0,65 & $2 ; 386$ & 3.17 & $.043 *$ & $1-2 ; 1-3 ; 2-3$ \\
\hline & 3 & 11 yıl ve üstü & 121 & 2,17 & 0,45 & & & & \\
\hline \multirow{3}{*}{$\begin{array}{l}\text { Örgütsel İş } \\
\text { Doyumu }\end{array}$} & 1 & 5 yıl ve altı & 109 & 2,41 & 0,95 & & & & \\
\hline & 2 & 6-10 yıl & 159 & 2,11 & 0,78 & $2 ; 386$ & 3.32 & $.037^{*}$ & $1-2 ; 1-3 ; 2-3$ \\
\hline & 3 & 11 yıl ve üstü & 121 & 1,87 & 0,46 & & & & \\
\hline \multirow{3}{*}{$\begin{array}{l}\text { Genel İş Doyum } \\
\text { Düzeyi }\end{array}$} & 1 & 5 yıl ve altı & 109 & 2,62 & 1,02 & & & & \\
\hline & 2 & 6-10 yıl & 159 & 2,29 & 0,715 & $2 ; 386$ & 3.22 & $.041^{*}$ & $1-2 ; 1-3 ; 2-3$ \\
\hline & 3 & 11 yıl ve üstü & 121 & 2,02 & 0,455 & & & & \\
\hline
\end{tabular}

${ }^{*} p<.05$

Tablo 6 incelendiğinde, katılımcıların mesleki kıdemleriyle iş doyumu düzeylerinin anlamlı olarak değiştiği görülmektedir $[F(2 ; 386)=3.22 ; p<.05]$. Mesleki kıdem, bireysel ve örgütsel iş doyumu alt boyutlarında anlamlı bir farklılık göstermektedir $(p<.05)$. İs doyumunun tüm alt boyutlarında ve genel iş doyumu ile mesleki kıdemin alt grupları arasındaki fark incelendiğinde 11 yıl ve üstü mesleki kıdeme sahip olanların, 6-10 yıl ve 5 yıl ve altı yıl kıdeme sahip olanlara göre daha az; 6-10 yıl mesleki kıdeme sahip olanların ise 
5 yıl ve altı kıdeme sahip olanlara göre daha az iş doyumuna sahip olduğu belirlenmiştir. Mesleki kıdemdeki artış iş doyumun azalmaya yol açmaktadır.

\section{iş Doyumu ile Öz Yeterlik Algıları Arasındaki Etkileşime ilişsin Bulgular}

DKAB öğretmenlerinin örgütsel adalet algılarının iş doyumlarını anlamlı bir şekilde yordama durumunu belirlemek amacıyla çoklu doğrusal regresyon analizi yapılmıştır. Yapılan analiz sonucunda elde edilen bulgular Tablo 7'de sunulmuştur.

Tablo 7

Örgütsel Adaletin Iş Doyumunu Açıklama Derecesine Iliş̧kin Çoklu Regresyon Analizi Sonuçları

\begin{tabular}{lccccc} 
Değişken & $\mathbf{B}$ & St. Hat. & $\mathbf{B}$ & $\mathbf{t}$ & $\mathbf{p}$ \\
Sabit & 48.93 & 2.242 & - & 22.612 & .000 \\
Dağıtımsal Adalet & .523 & .171 & .217 & 3.741 & .012 \\
İşlemsel Adalet & .265 & .165 & .161 & 2.191 & .041 \\
Etkileşimsel Adalet & .371 & .251 & .113 & 2.034 & .043 \\
\hline \multicolumn{1}{c}{$\mathrm{R}=.519$} & $\mathrm{R}^{2}=.269$ & $\mathrm{~F}(3,619)=42,724$ & $\mathrm{p}=.000$ & \\
\hline
\end{tabular}

Tablo 7'de DKAB öğretmenlerinin örgütsel adalet algılarının iş doyumlarını anlamlı bir şekilde yordama derecesine ilişkin yapılan çoklu doğrusal regresyon analizi görülmektedir. İlgili analiz sonucunda DKAB öğretmenlerinin örgütsel adalet algılarının iş doyumlarını anlamlı bir şekilde açıkladığı bulgusuna ulaşılmıştır $\left(R=.519, R^{2}=.269, p<.05\right)$. DKAB öğretmenlerinin, örgütsel adaletin alt boyutlarına ilişkin algıları iş doyumlarının \%27'sini açıklamaktadır. Dağıtımsal adalet $(p=.012<.05)$, işlemsel adalet $(p=.041<.05)$ ve etkileşimsel adalet $(p=.043<.05)$ modele anlamlı bir katkı sağlamaktadır DKAB öğretmenlerinin iş doyumlarındaki açıklanan varyansa en büyük katkıyı dağıtımsal adalet algıları yapmaktadır. Katılımcıların iş doyumları ile örgütsel adalet algıları arasındaki ilişki Tablo 8'de yer almaktadır.

Tablo 8

Katılımcıların Iş̧ Doyumları ile Örgütsel Adalet Algıları Arasındaki Ilişski

\begin{tabular}{llllllll}
\multicolumn{1}{c}{ Değişkenler } & $\overline{\mathbf{X}}$ & ss & $\mathbf{1}$ & $\mathbf{2}$ & $\mathbf{3}$ & $\mathbf{4}$ & $\mathbf{5}$ \\
1. Dağıtımsal Adalet & 3.41 & .85 & - & - & - & - & - \\
2. Iş̧lemsel Adalet & 3.21 & .91 & .52 & - & - & - & - \\
3. Etkileşimsel Adalet & 3.09 & .83 & .47 & .41 & - & - & - \\
\hline 4. Bireysel İ̧̧ Doyumu & 2.49 & .73 & $.69^{*}$ & $.76^{* *}$ & $.73^{*}$ & - & - \\
5. Örgütsel İş Doyumu & 2.13 & .69 & $.79^{* *}$ & $.77^{* *}$ & $.75^{* *}$ & .48 & - \\
\hline
\end{tabular}

$\mathrm{N}=389 ;{ }^{* *} \mathrm{p}<.01,{ }^{*} \mathrm{p}<.05$

Tablo 8 incelendiğinde dağıtımsal adalet ile örgütsel iş doyumu arasında yüksek; bireysel iş doyumu arasında orta düzeyli, anlamlı ve pozitif yönlü ilişki bulunmuştur. İşlemsel adalet ile bireysel ve örgütsel iş doyumu arasında pozitif yönlü, anlamlı ve orta düzeyli ilişki söz konusudur. Etkileşimsel adalet ile bireysel iş doyumu arasında pozitif yönlü, anlamlı ve orta düzeyli; örgütsel iş doyumu ile pozitif yönlü orta düzeyli, anlamlı ilişki belirlenmiştir. Değişkenler arasındaki en yüksek ilişki düzeyinin 79 olması, çoklu bağlantı sorununun bulunmadığına işaret etmektedir (Grewal, Cote, \& Baumgartner, 2004). 


\section{TARTIŞMA, SONUÇ VE ÖNERILER}

2017 yılında güncellen eğitim müfredatları ile tüm derslerde öğrencilere aktarılması hedeflenen kök değerlerden biri olan ve Milli Eğitim Bakanlığı tarafından yayınlanan 2023 Eğitim Vizyon Belgesinde sıkıkla vurgulanan adalet kavramı adalet kavramı, öğrencilere kuramsal bir bilgi aktarımından ziyade pratik olarak öğrencilerin deneyimlemesi ve içselleştirmesi gereken bir kavramdır. Öğrencilere adalet ve diğer kök değerleri sunmakla görevli öğretmenlerin, bu kavram ve değerleri benimsemiş ve içselleştirmiş olmaları ile yaşantılarında adilane uygulamalara yer vermeleri önemlidir. Öğretmenlerin tutum ve davranışlarında adalet gibi bir değer içselleştirilmeden, öğrencilerde istendik yönde davranış ve değer oluşumu söz konusu olamaz. Bu bakımdan bu çalışma, adalet kavramının sınırlı bir öğretmen örneklemi üzerindeki içselleşme derecesine odaklanmaktadır. Ayrıca çalışmada, DKAB öğretmenlerinin, okulda var olan örgütsel adalet algıları ile öğretmenlik mesleğine ilişkin iş doyumları belirlenmiş; ayrıca, örgütsel adalet ile iş doyumu arasındaki ilişkiler incelenmiştir.

Araştırma sonuçlarına göre, katılımcıların dağıtımsal, işlemsel ve etkileşimsel adalet algısına 'çoğunlukla' sahip oldukları belirlenmiştir. Benzer şekilde katılımcılar, genel örgütsel adalet algısına da 'çoğunlukla' sahiptirler. Katılımcıların 'orta' düzeyde bireysel ve 'az' düzeyde örgütsel iş doyumuna sahip oldukları saptanmıştır. Ayrıca katılımcıların genel iş doyumu seviyesi de 'az' düzeydedir. Bununla birlikte dağıtımsal, işlemsel ve etkileşimsel adalet cinsiyet, eğitim durumu, okul türü ve mesleki kıdeme göre anlamlı bir şekilde farklılaşmaktadır. Bunun yanında dă̆ıtımsal adalet ile örgütsel iş doyumu ve bireysel iş doyumu arasında orta düzeyli bir ilişki vardır. İşlemsel adalet ile bireysel ve örgütsel iş doyumu arasında pozitif yönlü, anlamlı ve orta düzeyli; etkileşimsel adalet ile bireysel iş doyumu arasında pozitif yönlü, anlamlı ve orta düzeyli; örgütsel iş doyumu ile orta düzeyli bir ilişki belirlenmiştir. DKAB öğretmenlerinin, örgütsel adaletin alt boyutlarına ilişkin algıları iş doyumlarının \%27'sini açıklamaktadır.

Örgütsel adalet algısına etki ettiği düşünülen çok sayıda bireysel, örgütsel ve çevresel unsur bulunmaktadır. Bununla birlikte iş doyumu ve örgütsel adalet konusu farklı araştırmalarda çalışımış (Bakhshi vd., 2009; Imran vd., 2015; Khany \& Tazik, 2016; Nadiri \& Tanova, 2010) ve bu araştırmaların büyük çoğunluğunda, bu çalışma ile belirlenen "örgütsel adalet ile iş doyumu arasında anlamlı ve pozitif yönlü ilişkilerin bulunduğu" sonucuna ulaşılmıştır (Colquitt vd., 2005; Leung vd., 1996, 1996; Ouyang vd., 2015). Genelde iş yaşamında ve özelde ise okullarda, insan kaynağının etkili ve üretken kullanılabilmesi, çalışanların iş doyumlarının ve bunun öncüllerinden olan örgütsel adaletin sağlanması ile mümkündür (Cropanzano vd., 2001; López-Cabarcos vd., 2015). Kaynakların adil dağıtılmadığı, kaynak dağıtım sürecinin şeffaf olmadığı ve adalet duygusunun tüm çalışanlarca benzer şekilde algılanmadığı örgütlerde, çalışanlarda işe karşı isteğin, iş motivasyonunun veya iş doyumunun olduğuna yönelik emareler bulunmaz (Zainalipour vd., 2010).

Bu araştırma kapsamında DKAB öğretmenlerinin 'orta' düzeyde örgütsel adalet algısının olduğu bulgusu önemlidir. Söz konusu bulgu literatürde farklı araştırma bulgularıyla desteklenmektedir (Baş \& Şentürk, 2011; Polat, 2007; Sezgin, 2005). Buna karşın literatürde örgütsel adalet algısının öğretmenler arasında düşük düzeyde olduğuna dair sonuçlara da ulaşılmıştır (Altahayneh vd., 2014; Zainalipour vd., 2010). DKAB öğretmenleri, dağıtımsal adalet boyutunda orta düzeyde bir algıya sahipken, etkileşimsel adalet algısı nispeten düşük düzeydedir. Çalışmanın bu sonucu literatürdeki farklı araştırmalarla paralellik göstermektedir (López-Cabarcos vd., 2015; Nordhall \& Knez, 2018). DKAB Öğretmenlerin dağıtımsal adalet algılarının orta düzeyde olması: öğretmenlere verilen ödül ve cezalarda adil ve geçerli ölçütlerin bulunmaması, tüm öğretmenler tarafından kabul görmüş tutarlı bir ödül sisteminin eksikliği, öğretmenlerin çalışmalarının takdir edilmemesi, ödül ve ceza verilmesinde okul yöneticilerinin tarafsız ve 
adil olmaması gibi unsurlar etkili olmaktadır (Altahayneh vd., 2014; Özer \& Urtekin, 2007; Polat, 2007; Yelboğa, 2012).

Araştırmanın diğer bulgusu olan DKAB öğretmenlerinin işlemsel adalet algılarının orta seviyede olması, literatürdeki çeşitli çalışmalarla benzerlik göstermektedir (Chughtai \& Zafar, 2006; Ololube, 2006; Zeinabadi \& Salehi, 2011). İşlemsel adalet, okul yönetiminin aldığı karar ve okul içi uygulamalarında adalet ilkesini ön planda tutmasıdır. Okul yöneticilerinin, hak ve hukuk kurallarını gözeterek karar almadığı durumlarda, genellikle mesleki kıdemi fazla olan veya kendisi ile benzer politik, dini, etnik köken ile sendika üyeliğine sahip öğretmenlere karşı pozitif ayrımcılık yapma eğiliminde olduğuna yönelik araştırma bulgularına rastlanmaktadır (Folger \& Cropanzano, 1998; Malik, Nawab, Naeem, \& Danish, 2010). Yöneticilerin, kaynak edinimi ve dağıtımı sürecinde aldıkları kararlarda çalışanlara karşı takındıkları tutum ve davranışlar ile çalışanların, yönetici ve diğer çalışanlara karşı tutum ve davranışları etkileşimsel adalettir. Bu araştırma ile DKAB öğretmenlerinin etkileşimsel adalet algılarının, diğer adalet boyutlarına göre düşük seviyede tespit edilmesi önemlidir. Çalışmanın söz konusu bulgusu literatürde farklı kaynaklarla benzeşim göstermektedir (Colquitt vd., 2005; Harris vd., 2004; Leung vd., 1996). Etkileşimsel adalet, çoğunlukla örgüt içi iletişim kanallarında yaşanan aksaklıklar, kişilerin izlenimlerini iyi yönetememesi, yönetici-öğretmen iletişiminde yaşanan yanlılık ve gruplaşmalar gibi farklı unsurlardan etkilenmektedir. Okullarda her öğretmenin yönetici ile profesyonel bir ilişki geliştirmesi elzemdir. Özel ilişkilerinde sorunlar yaşasalar dahi yönetici ve öğretmenin kuracağı profesyonel ilişkiler, okulun daha tutarlı ve etkin bir şekilde yönetilmesine katkı sağlar (Greenberg, 1990; Imran vd., 2015; Moorman vd., 1993). Okulda çalışanlar arasında pozitif ve yapıcı iletişim kurulması ile hedeflere ulaşmak da kolaylaşacaktır.

Bu çalışmada DKAB öğretmenlerin genel iş doyum düzeylerinin 'düşük' seviyede olduğu belirlenmiştir. Söz konusu bulgu literatürdeki farklı araştırma bulguları ile benzerlik göstermektedir (Baltaci, 2017; Eker, 2006; Nadiri \& Tanova, 2010; Özer \& Urtekin, 2007; Yelboğa, 2012; Zeinabadi \& Salehi, 2011). Buna karşın bazı araştırmalarda öğretmen iş doyumunun 'orta' seviyede olduğu (Khany \& Tazik, 2016; Polat \& Celep, 2008; Sezgin, 2005); bazılarında ise 'yüksek' seviyede olduğu bulunmuştur (Eisenberger, Cummings, Armeli, \& Lynch, 1997; Nagar, 2012). Dikkat çekici bir nokta öğretmen iş doyumunun yüksek olduğu sonucuna ulaşan araştırmaların yurtdışında yapılmış olmasıdır. Son 30 yılda Türkiye'de yapılan iş doyumu araştırmalarında öğretmenlerin, çoğunlukla 'orta' ve 'düşük' seviyelerde iş doyumlarının olduğu sonucu önemlidir (Aydin, Sarier, \& Uysal, 2013). Bununla birlikte DKAB öğretmenlerinin bireysel iş doyumlarının, örgütsel iş doyumlarına göre nispeten daha yüksek seviyede olması da dikkat çekicidir. Araştırmanın bu bulgusu pek çok araştırma bulgusu ile örtüşmektedir (Baltaci, 2017; Koustelios, 2001; Malik vd., 2010; Özer \& Urtekin, 2007; Zeinabadi \& Salehi, 2011). Öğretmenlik mesleğinin toplumsal statüsü ile öğretmenlerin yapageldikleri işin önemli olduğuna yönelik algıları bireysel iş doyum düzeylerinin, örgütsel iş doyumuna göre yüksek olmasına yol açmış olabilir (Bilgiç, 1998; Ostroff, 1992). Bununla birlikte, geleceği şekillendiren bir mesleğe ilişkin toplumsal algının medyada çıkan çeşitli haberler ve diğer etkenler tarafından olumsuz yönde şekillendirilmesi, öğretmenlere sunulan maddi imkânların yetersizliği, çalışma koşullarının ve yöneticilerin gayrimeşru tutum ve davranışları gibi çok sayıda etken de örgütsel iş doyumunun düşük seviyede olmasına yol açmış olabilir (Griffith, 2004; Hülsheger vd., 2013; Klassen \& Chiu, 2010). Ancak her durumda DKAB öğretmenlerine yönelik iş doyumunun düşük seviyede olması, din eğitimi politikalarının toplumsal zemine ulaşması bakımından engel oluşturmaktadır. Çünkü iş doyumu sağlanamamış bir öğretmen, işe yabancılaşmakta, okulda ve derslerde sosyal medya veya diğer etkinliklerle vakit geçirmekte ve derslere dair rutin işleri yapmış olmak için yapmaktadır (Crossman \& Harris, 2006; Khany \& Tazik, 2016; Nadiri \& Tanova, 2010; Okpara, 2004). Böylesi bir durum din eğitimine yönelik kazanımların öğrencilerde istendik şekilde oluşturulmasının önünde önemli bir tehdittir. Ayrıca 
bu durum, son yıllarda önemli ölçüde kaynak ayrılan din eğitimi alanında kaynakların heba edilmesi anlamına da gelmektedir.

Ayrıca bu çalışmada DKAB öğretmenlerindeki iş doyum düzeyinde örgütsel adalet algısının önemli bir etkisi olduğu sonucuna ulaşılmıştır. Bu sonuç farklı araştırmalarla desteklenmektedir. Folger ve Cropanzano (1998) ile Yıldız (2012), örgütsel adaletin iş doyumunun önemli bir unsuru olduğunu belirlemişlerdir. Literatürde bu araştırma bulguları arasında yer alan dağıtımsal adaletin, iş doyumu üzerinde daha fazla etkisi olduğu sonucuna ulaşan çalışmalarda bulunmaktadır (Cropanzano vd., 2001; Folger \& Cropanzano, 1998; McFarlin \& Sweeney, 1992; Yavuz, 2010; Yıldız, 2012). Ayrıca bu araştırmanın diğer bir bulgusu da DKAB öğretmenlerinin örgütsel adalet algısı ile iş doyumu arasında yüksek düzeyli, anlamlı ve pozitif yönlü bir ilişkinin var olduğu bulgusu, literatürde çok sayıda araştırma ile desteklenmektedir (Aydin vd., 2013; Bakhshi vd., 2009; Khany \& Tazik, 2016; Zeinabadi \& Salehi, 2011). Literatürde okul yöneticilerinin, öğretmenlere karşı dağıtımsal, işlemsel ve etkileşimsel adalet boyutlarında hak ve hukuk gözetmedikleri ve bu durumun bireysel ve örgütsel iş doyumuna olumsuz yönde etkisinin olduğu bildirilmektedir (Eker, 2006; Özer \& Urtekin, 2007; Özgan \& Bozbayindir, 2011; Yavuz, 2010). Öğretmenlerin performans gözetilmeksizin, taraflı bir şekilde ödüllendirilmesi; okul veya öğretmenlerle ilgili kararlarda yönetime yakın öğretmenlerin görüşlerine riayet edilmesi; okul içi veya dışı görevlendirmelerde yanlıık; ders dağıtım ve ders programlarında yapılan ayrımcılık; nöbet görev yerlerinin yanlı olarak dağıtılması veya belirli öğretmenlere nöbet görevi verilmemesi; sevk ve raporlarda belirli öğretmenlere pozitif ayrımcılık yapılması ile düşük sicil notu verme gibi uygulamalar okul yöneticilerinin bu tutumuna delil olarak gösterilebilir (Baltaci, 2017; Baş \& Şentürk, 2011; Polat \& Celep, 2008; Sezgin, 2005). Adil olmayan ve çoğu kez usulsüz olan bu iş ve işlemler, DKAB öğretmenlerinin işlerinden daha az doyum sağlamalarına yol açarken, tersi durumda yani okul içi adaletin sağlandığı durumda öğretmenlerin daha yüksek iş doyumu sağlamaları mümkün olabilir (Leung vd., 1996; Nordhall \& Knez, 2018; Yildirim, 2007).

Araştırmadan elde edilen sonuçlara dayalı olarak uygulamaya ve araştırmaya dönük çeşitli öneriler geliştirilmiştir:

- DKAB öğretmenlerinin örgütsel adalet algısının, bireysel ve örgütsel iş doyumlarında önemli etkiye sahip olmasından hareketle okulların adilane bir şekilde yönetilmesi ile öğretmenlerin iş doyumlarının arttırılabileceği söylenebilir. Eğitim politikalarına yön verenlerin, okullarda etik yönetim ilkelerine uygun, öğretmenler arasında ayrımcılığın yapılmadığı daha saydam ve hesapverebilir bir yönetim anlayışını okullarda egemen kılması gereklidir. Bu noktada, yönetici ve öğretmen değerlendirme ölçütleri gözden geçirilebilir ve bir süredir askıya alınan ders ve kurum denetimleri yeniden işler hale getirilebilir.

- $\quad$ DKAB öğretmenlerinin iş doyum düzeylerinin önemli oranda düşük olması kaygı vericidir. İş doyumu, öğretmenin yaşamını doğrudan etkilemekte ve okul içi veya dışında yoğun stres yaşamasına neden olabilmektedir (Crossman \& Harris, 2006). Stres ise depresyon ve çeşitli duygu-durum bozukluklarına yol açan önemli bir durumdur. Özelde DKAB öğretmenleri ile genelde tüm öğretmenlerin, anılan duygu-durum bozulmalarını yaşamadan önce tedbirler alınması gereklidir. İş yeri hekimliği bu noktada önemli bir kaynaktır. Ancak çoğu okulda iş yeri hekimi veya İş Güvenliği Uzmanı bulunmamaktadır. Var olan uzmanların ise çalışanların duygusal problemlerine yoğunlaştıkları söylenemez. Bu noktada Toplum Sağlığı Merkezlerinden uzman psikolog ve sosyal çalışmacıların işe koşulması ve öğretmenlerdeki iş doyumu ve diğer duygudurum sorunlarını çözebilecek uygulamaların yürütülmesi gereklidir.

- DKAB öğretmenlerinin iş doyumları, okullardaki biçimsel ve biçimsel olmayan sosyal ilişkilerden ve kişisel gereksinimlerden çoğunlukla etkilenmektedir. Bu sebeple okul içinde personel 
güçlendirmesi yapılarak çalışanlar arası sosyal bağlar oluşturulması, okul içi karar süreçlerinde tüm öğretmen ve gerekiyorsa diğer çalışanlarında katılımının sağlanması önerilebilir.

- Nicel bir desene sahip olan bu araştırmadan hareketle ileride yapılacak çalışmalarda, nitel araştırmanın ayrıntıları belirginleştiren ve değişkenler arası etkileşimleri açıklayabilen doğasından faydalanılarak nitel veya karma desende yürütülebilir. Bunun yanında farklı öğretmenlik alanları daha ayrıntılı çalışılarak çeşitli karşılaştırmalara gidilebilir.

- Bu çalışma dar bir örneklem çerçevesinde yürütülmüş ve DKAB öğretmenlerinin örgütsel adalet algıları ve iş doyum düzeylerini belirlemeyi amaçlamıştır. Ileride yapılacak çalışmalarda örgütsel davranışın farklı kavramları ele alınıp iş doyumu ve örgütsel adalet kavramları arasındaki ilişkiler detaylı bir şekilde incelenebilir.

\section{KAYNAKÇA}

Altahayneh, Z. L., Khasawneh, A., \& Abedalhafiz, A. (2014). Relationship between organizational justice and job satisfaction as perceived by Jordanian physical education teachers. Asian Social Science, 10(4), 131.

Altaş, N. (2004). Gençlik döneminde din olgusu ve liselerde din öğretimi. Nobel.

Aryee, S., Budhwar, P. S., \& Chen, Z. X. (2002). Trust as a mediator of the relationship between organizational justice and work outcomes: Test of a social exchange model. Journal of Organizational Behavior: The International Journal of Industrial, Occupational and Organizational Psychology and Behavior, 23(3), 267-285.

Aydin, A., Sarier, Y., \& Uysal, S. (2013). The Effect of School Principals' Leadership Styles on Teachers' Organizational Commitment and Job Satisfaction. Educational sciences: Theory and practice, 13(2), 806-811.

Bakhshi, A., Kumar, K., \& Rani, E. (2009). Organizational justice perceptions as predictor of job satisfaction and organization commitment. International journal of Business and Management, 4(9), 145.

Baltacı, A., \& Coşkun, M. K. (2018). Din dersi öğretmenlerine yönelik öğretmen algısı ölçeğinin geliştirilmesi. OPUS Uluslararası Toplum Araştırmaları Dergisi, 8(15), 1450-1473.

Baltaci, A. (2017). Okul müdürlerinin iş doyumları ile öz yeterlik algıları arasındaki ilişki. Ihlara Eğitim Araştırmaları Dergisi, 2(1), 49-76.

Baş, G., \& Şentürk, C. (2011). illköğretim okulu öğretmenlerinin örgütsel adalet, örgütsel vatandaşlık ve örgütsel güven algıları. Kuram ve Uygulamada Egitim Yönetimi Dergisi, 17(1), 29-62.

Başaran, i. E. (2004). Yönetimde insan ilişkileri: Yönetsel davranış. Nobel Yayın Dağıım.

Bayrakdar, N. (2014). Din Kültürü ve Ahlak Bilgisi Öğretmenlerinin Mesleklerinden Beklentileri ve Mesleki Tükenmişlik Algıları. Erciyes Üniversitesi Sosyal Bilimler Enstitüsü Dergisi, 1(37), 40-60.

Bies, R. J., \& Shapiro, D. L. (1988). Voice and justification: Their influence on procedural fairness judgments. Academy of Management Journal, 31(3), 676-685.

Bilgiç, R. (1998). The relationship between job satisfaction and personal characteristics of Turkish workers. The Journal of Psychology, 132(5), 549-557.

Brighouse, H. (2003). School choice and social justice. Oxford University Press, USA.

Brown, S. P., \& Peterson, R. A. (1993). Antecedents and consequences of salesperson job satisfaction: Meta-analysis and assessment of causal effects. Journal of Marketing Research (JMR), 30(1).

Chughtai, A. A., \& Zafar, S. (2006). Antecedents and consequences of organizational commitment among Pakistani university teachers. Applied H.R.M. Research, 11(1), 39-64.

Cohen, R. L. (1987). Distributive justice: Theory and research. Social Justice Research, 1(1), 19-40.

Colquitt, J. A., Conlon, D. E., Wesson, M. J., Porter, C. O., \& Ng, K. Y. (2001). Justice at the millennium: a meta-analytic review of 25 years of organizational justice research. Journal of Applied Psychology, 86(3), 425-445. 
Colquitt, J. A., Greenberg, J., \& Zapata-Phelan, C. P. (2005). What is organizational justice? A historical overview. Handbook of Organizational Justice, 1, 3-58.

Cropanzano, R., Byrne, Z. S., Bobocel, D. R., \& Rupp, D. E. (2001). Moral virtues, fairness heuristics, social entities, and other denizens of organizational justice. Journal of Vocational Behavior, 58(2), 164209.

Crossman, A., \& Harris, P. (2006). Job satisfaction of secondary school teachers. Educational Management Administration \& Leadership, 34(1), 29-46.

Croux, C., \& Dehon, C. (2010). Influence functions of the Spearman and Kendall correlation measures. Statistical Methods \& Applications, 19(4), 497-515.

Çarkoğlu, A., \& Toprak, B. (2006). Değişen Türkiye'de din, toplum ve siyaset. TESEV.

Davis, K. (1988). İşletmede İnsan Davranışı: Örgütsel Davranış, Çev. Kemal Tosun, 5, 8.

de Bustillo Llorente, R. M., \& Macias, E. F. (2005). Job satisfaction as an indicator of the quality of work. The Journal of Socio-Economics, 34(5), 656-673.

Deal, T. E., \& Peterson, K. D. (2016). Shaping school culture. John Wiley \& Sons.

DiPaola, M., \& Tschannen-Moran, M. (2014). Organizational citizenship behavior in schools and its relationship to school climate. Journal of School Leadership, 11(5), 424-447.

Eisenberger, R., Cummings, J., Armeli, S., \& Lynch, P. (1997). Perceived organizational support, discretionary treatment, and job satisfaction. Journal of Applied Psychology, 82(5), 812.

Eker, G. (2006). Örgütsel adalet algısı boyutları ve iş doyumu üzerindeki etkileri (Yüksek Lisans Tezi). Dokuz Eylül Üniversitesi Sosyal Bilimleri Enstitüsü, İzmir.

Erdoğan, M. (2003). Anayasal demokrasi (C. 5). Siyasal Kitabevi.

Folger, R. G., \& Cropanzano, R. (1998). Organizational justice and human resource management (C. 7). Sage.

Gamero Burón, C., \& Lassibille, G. (2016). Job satisfaction among primary school personnel in Madagascar. The Journal of Development Studies, 52(11), 1628-1646.

Greenberg, J. (1990). Organizational justice: Yesterday, today, and tomorrow. Journal of Management, 16(2), 399-432.

Greenberg, J., \& Colquitt, J. A. (2013). Handbook of organizational justice. Psychology Press.

Grewal, R., Cote, J. A., \& Baumgartner, H. (2004). Multicollinearity and measurement error in structural equation models: Implications for theory testing. Marketing Science, 23(4), 519-529.

Griffith, J. (2004). Relation of principal transformational leadership to school staff job satisfaction, staff turnover, and school performance. Journal of Educational Administration, 42(3), 333-356.

Harris, M. M., Lievens, F., \& Van Hoye, G. (2004). "I think they discriminated against me": using prototype theory and organizational justice theory for understanding perceived discrimination in selection and promotion situations. International Journal of Selection and Assessment, 12(1-2), 54-65.

Hülsheger, U. R., Alberts, H. J., Feinholdt, A., \& Lang, J. W. (2013). Benefits of mindfulness at work: the role of mindfulness in emotion regulation, emotional exhaustion, and job satisfaction. Journal of Applied Psychology, 98(2), 310.

İçerli, L. (2010). Örgütsel adalet: kuramsal bir yaklaşım. Girişimcilik ve Kalkınma Dergisi, 5(1), 67-92.

Imran, R., Majeed, M., \& Ayub, A. (2015). Impact of organizational justice, job security and job satisfaction on organizational productivity. Journal of Economics, Business and Management, 3(9), 840-845.

Khany, R., \& Tazik, K. (2016). On the relationship between psychological empowerment, trust, and Iranian EFL teachers' job satisfaction: The case of secondary school teachers. Journal of Career Assessment, 24(1), 112-129.

Klassen, R. M., \& Chiu, M. M. (2010). Effects on teachers' self-efficacy and job satisfaction: Teacher gender, years of experience, and job stress. Journal of Educational Psychology, 102(3), 741. 
Koedel, C., Li, J., Springer, M. G., \& Tan, L. (2017). The impact of performance ratings on job satisfaction for public school teachers. American Educational Research Journal, 54(2), 241-278.

Koustelios, A. D. (2001). Personal characteristics and job satisfaction of Greek teachers. International Journal of Educational Management, 15(7), 354-358.

Leung, K., Smith, P. B., Wang, Z., \& Sun, H. (1996). Job satisfaction in joint venture hotels in China: An organizational justice analysis. Journal of International Business Studies, 27(5), 947-962.

Lind, E. A. (2001). Fairness heuristic theory: Justice judgments as pivotal cognitions in organizational relations. Advances in Organizational Justice, 56(8).

López-Cabarcos, M. Á., Machado-Lopes-Sampaio-de Pinho, A. I., \& Vázquez-Rodríguez, P. (2015). The influence of organizational justice and job satisfaction on organizational commitment in Portugal's hotel industry. Cornell Hospitality Quarterly, 56(3), 258-272.

Malik, M. E., Nawab, S., Naeem, B., \& Danish, R. Q. (2010). Job satisfaction and organizational commitment of university teachers in public sector of Pakistan. International Journal of Business and Management, 5(6), 17.

Martin, J. (2018). Screening the sacred: Religion, myth, and ideology in popular American film. Routledge.

McFarlin, D. B., \& Sweeney, P. D. (1992). Distributive and procedural justice as predictors of satisfaction with personal and organizational outcomes. Academy of Management Journal, 35(3), 626-637.

Michaelowa, K. (2002). Teacher job satisfaction, student achievement, and the cost of primary education in Francophone Sub-Saharan Africa. HWWA Discussion Paper.

Mobley, W. H. (1977). Intermediate linkages in the relationship between job satisfaction and employee turnover. Journal of Applied Psychology, 62(2), 237.

Moorman, R. H., Niehoff, B. P., \& Organ, D. W. (1993). Treating employees fairly and organizational citizenship behavior: Sorting the effects of job satisfaction, organizational commitment, and procedural justice. Employee Responsibilities and Rights Journal, 6(3), 209-225.

Nadiri, H., \& Tanova, C. (2010). An investigation of the role of justice in turnover intentions, job satisfaction, and organizational citizenship behavior in hospitality industry. International Journal of Hospitality Management, 29(1), 33-41.

Nagar, K. (2012). Organizational commitment and job satisfaction among teachers during times of burnout. Vikalpa, 37(2), 43-60.

Nordhall, O., \& Knez, I. (2018). Motivation and Justice at Work: The Role of Emotion and Cognition Components of Personal and Collective Work Identity. Frontiers in Psychology, 8, 2307.

Okpara, J. O. (2004). Personal characteristics as predictors of job satisfaction: An exploratory study of IT managers in a developing economy. Information Technology \& People, 17(3), 327-338.

Ololube, N. P. (2006). Teachers job satisfaction and motivation for school effectiveness: An assessment. Online Submission.

Ostroff, C. (1992). The relationship between satisfaction, attitudes, and performance: An organizational level analysis. Journal of applied psychology, 77(6), 963.

Ouyang, Z., Sang, J., Li, P., \& Peng, J. (2015). Organizational justice and job insecurity as mediators of the effect of emotional intelligence on job satisfaction: A study from China. Personality and Individual Differences, 76, 147-152.

Özer, P. S., \& Urtekin, G. E. (2007). Örgütsel adalet algısı boyutları ve iş doyumu ilişkisi üzerine bir araştırma. Erciyes Üniversitesi iktisadi ve Idari Bilimler Fakültesi Dergisi, (28), 107-125.

Özgan, H., \& Bozbayındır, F. (2011). Okullarda adil olmayan uygulamalar ve etkileri. Dicle University Journal of Ziya Gokalp Education Faculty, 16, 66-85.

Polat, S. (2007). Örgütsel güven, adalet ve vatandaşlık davranışlarına ilişkin öğretmen algıları (Doktora Tezi). Kocaeli Üniversitesi Sosyal Bilimler Enstitüsü, Kocaeli. 
Polat, S., \& Celep, C. (2008). Ortaöğretim öğretmenlerinin örgütsel adalet, örgütsel güven, örgütsel vatandaşlık davranışlarına ilişkin algıları. Kuram ve Uygulamada Eğitim Yönetimi Dergisi, 14(2), 307-331.

Saruhan, M. (2015). Erdemlerin Erdemi: Adâlet. Adam Akademi Sosyal Bilimler Dergisi, 5(1), 1-12.

Scott, C., \& Dinham, S. (2003). The development of scales to measure teacher and school executive occupational satisfaction. Journal of Educational Administration, 41(1), 74-86.

Sezgin, F. (2005). Örgütsel vatandaşlık davranışları: Kavramsal bir çözümleme ve okul açısından bazı çıkarımlar. Gazi Üniversitesi Gazi Eğitim Fakültesi Dergisi, 25(1).

Shariff, A. F., Willard, A. K., Andersen, T., \& Norenzayan, A. (2016). Religious priming: A meta-analysis with a focus on prosociality. Personality and Social Psychology Review, 20(1), 27-48.

Skaalvik, E. M., \& Skaalvik, S. (2011). Teacher job satisfaction and motivation to leave the teaching profession: Relations with school context, feeling of belonging, and emotional exhaustion. Teaching and Teacher Education, 27(6), 1029-1038.

Skarlicki, D. P., \& Latham, G. P. (1996). Increasing citizenship behavior within a labor union: A test of organizational justice theory. Journal of applied psychology, 81(2), 161.

Somech, A., \& Drach-Zahavy, A. (2000). Understanding extra-role behavior in schools: The relationships between job satisfaction, sense of efficacy, and teachers' extra-role behavior. Teaching and Teacher Education, 16(5-6), 649-659.

Spector, P. E. (1985). Measurement of human service staff satisfaction: Development of the job satisfaction survey. American Journal of Community Psychology, 13(6), 693-713.

Szeto, E. (2015). Community of Inquiry as an instructional approach: What effects of teaching, social and cognitive presences are there in blended synchronous learning and teaching?. Computers \& Education, 81, 191-201.

Thompson, D. P., McNamara, J. F., \& Hoyle, J. R. (1997). Job satisfaction in educational organizations: A synthesis of research findings. Educational Administration Quarterly, 33(1), 7-37.

Vogt, W. P. (2006). Quantitative research methods for professionals in education and other fields. $\mathrm{OH}$ : Allyn \& Bacon.

Vroom, V. H. (1962). Ego-involvement, job satisfaction, and job performance. Personnel psychology, 15(2), 159-177.

Wanous, J. P., Reichers, A. E., \& Hudy, M. J. (1997). Overall job satisfaction: How good are single-item measures? Journal of applied Psychology, 82(2), 247.

Witte, J. (2006). God's Joust, God's Justice: Law and religion in the Western tradition. Wm. B. Eerdmans Publishing.

Yavuz, S. (2010). Örgütsel adaletin iş tatminine etkisi üzerine bir araştırma (Yüksek Lisans Tezi). Marmara Üniversitesi Sosyal Bilimleri Enstitüsü. İstanbul.

Yelboğa, A. (2012). Örgütsel adalet ile iş doyumu ilişkisi: Ampirik bir çalışma. Ege Akademik Bakış, 12(2), 171-182.

Yıldız, K. (2012). Öğretmenlerin örgütsel adalet ve örgütsel güven algıları. Abant İzzet Baysal Üniversitesi Sosyal Bilimler Enstitüsü Dergisi, 26(26), 289-316.

Yildirim, F. (2007). İş doyumu ile örgütsel adalet ilişkisi. Ankara Üniversitesi SBF Dergisi, 62(1), 253-278.

Zainalipour, H., Fini, A. A. S., \& Mirkamali, S. M. (2010). A study of relationship between organizational justice and job satisfaction among teachers in Bandar Abbas middle school. Procedia-Social and Behavioral Sciences, 5, 1986-1990.

Zeinabadi, H., \& Salehi, K. (2011). Role of procedural justice, trust, job satisfaction, and organizational commitment in Organizational Citizenship Behavior (OCB) of teachers: Proposing a modified social exchange model. Procedia-Social and Behavioral Sciences, 29, 1472-1481.

Zembylas, M., \& Papanastasiou, E. C. (2005). Modeling teacher empowerment: The role of job satisfaction. Educational Research and Evaluation, 11(5), 433-459. 